\title{
Liquidated Damages in Californiat
}

\author{
Justin Sweet*
}

The extent of party autonomy ${ }^{1}$ given contracting parties depends upon the particular transaction and, to a degree, the subject of the particular contract clause in question. This Article examines the amount of autonomy given contracting parties to "liquidate" or fix the amount of damages for contract breach. Part I discusses the basic policy considerations and trends im party autonomy; part II considers the various types of contractual clauses controlling damages; part III is an overview of the California cases considering the enforceabihity of hquidation clauses; part IV explaims what criteria are articulated by courts in these cases and what criteria are actually used; and part V suggests legislative reform of the present system.

+ This Article was prepared to provide the California Law Revision Commission with background information for its study of various aspects of contracts. The author's opinions, conclusions, and recommeudations contained herein do not necessarily represent the views of the commission.

* Professor of Law, University of California, Berkeley. B.A. 1951, LL.B. 1953, University of Wisconsm. James M. Crawford, a recent graduate of the School of Law, University of California, Berkeley, provided invaluable research assistance.

1. The term "party autonomy" is used rather than the more commonly used "freedom of contract," because I believe the former more accurately expresses the power given by the state to parties to make their own rules and determine how risks will be allocated between them. The latter, strictly speaking, expresses only that parties have the power to make contracts.

2. A liquidated damages clause is one that attempts to make certain the amount of damages recoverable. Sometimes the term "agreed damages" is used. See, e.g., MacNeil, Power of Contract and Agreed Remedies, 47 Cornell L.Q. 495 (1962). In a sense this is more accurate than "liquidated damages," because clauses controlling damages often go beyond "liquidating" damages in the sense of specifying an amount or a mathematical formula. Yet "agreed damages" suggests two different meanings: it can mean that the parties have agreed that this amount or this formula will be used to compute damages for the breach in question or it can mean that the parties have agreed that the damages are likely to be a designated amount. If it is used in the first sense, the term "agreed damages" may be even more aecurate than "liquidated damages." However, if it is used in the seeond sense, it overdignifies the estimation-of-damages process, for, as we shall see, agreement does not occur in many situations. Another term used is "stipulated damages," which means that the parties in a negotiated contract (or the dominant party in an adhesion contract) have specified that a certain amount is to be paid iu the event a particular breach occurs. This is more accurate than the other terms, because they place too great an emphasis upon the amount as a true attempt to estimate what the damages are likely to be. However, because the term "liquidated damages" has received almost universal usage, it is used in this Article. 


\section{Policy Considerations and Trends in Party Autonomy}

The question of how much autonomy the law should give parties to employ clauses that control the amount of damages recoverable for contract breach is part of the general issue of party autonomy. Even in periods of maximum party autonomy, there have been some controls on contractmaking, such as the Statute of Frauds, capacity requirements, legality requirements, and usury laws. Also, the consideration doctrine limited pure contractual freedom by not enforcing gift promises and by balancing extremely unequal bargaining power through the mutuality concept. Until the 20th century, however, the general norm was party autonomy.

The most important reason for the modern trend away from autonomy is that much of 19th-century contract law was predicated upon the model of a contract between two parties of relatively equal bargaining power who negotiate and conclude a mutually acceptable agreement. Instead, the bulk of contracts today are various forms of adhesion contracts, the mass-produced, nonnegotiated contracts pioneered by the insurance, utilities, and transportation industries. ${ }^{3}$ The consent in these adhesion contracts is a fiction. The party handed a form usually has no time to read it, would not understand it if he took the time, would not be able to find anyone with authority to change it if he wished to, and very likely would not be able to make the transaction if he insisted upon a change from the standard form. ${ }^{4}$

Largely because of adhesion contracts, the past 20 years have seen a proliferation of legal controls on contracts. There is more judicial intervention through the back door of interpretation ${ }^{5}$ and, imcreasingly now, direct intervention through refusal to enforce contracts that courts think are unjust. ${ }^{6}$ There is also more control of standardized contracts by state and federal regulatory agencies; ${ }^{7}$ sec-

3. See generally Kessler, Contracts of Adhesion-Some Thoughts About Freedom of Contract, 43 Colum. L. REv. 629 (1943); Slawson, Standard Form Contracts and Democratic Control of Lawmaking Power, 84 HARv. L. Rev. 529 (1971).

4. See La Sala v. American Sav. and Loan Ass'n, 5 Cal. 3d 864, 489 P.2d 1113, 97 Cal. Rptr. 849 (1971); English v. Ford, 17 Cal. App. 3d 1038, 1050 n.10, 95 Cal. Rptr. 501, 508 n.10 (2d Dist. 1971); Bauer v. Jackson, 15 Cal. App. 3d 358, 93 Cal. Rptr. 43 (4th Dist. 1971).

5. See Steven v. Fidelity \& Cas. Co., 58 Cal. $2 d$ 862, 377 P.2d 284, 27 Cal. Rptr. 172 (1962).

6. See Tunkl v. Regents of University of California, 60 Cal. 2d 92, 383 P.2d 441, 32 Cal. Rptr. 33 (1963); Ellsworth Dobbs, Inc. v. Johnson, 50 N.J. 528, 236 A.2d 843 (1967); Henningsen v. Bloomfield Motors, Inc., 32 N.J. 358, 161 A.2d 69 (1960).

7. See Davidian v. Pacific Tel. \& Tel. Co., 16 Cal. App. 3d 750, 94 Cal. Rptr. 337 (2d Dist. 1971); Product Research Associates v. Pacific Tel. \& Tel. Co., 16 Cal. 
tion 2-302 of the Uniform Commercial Code directly invites courts to police the worst aspects of all standardized sales contracts and a proliferation of legislation controls contracts and contractmaking in particular situations. ${ }^{8}$ This increased legal control, however, must be seen against the backdrop of a large residue of party autonomy. We have moved from the 19 th century of relatively free autonomy to a mixed system in the 20th century: now some transactions are highly regulated, while others still have minimal legal control.

\section{A. Reasons for Liquidated Damages Provisions}

As the norm has changed from negotiated contract to adhesion contract, the reasons for employing liquidated damages clauses have changed, and accompanying this has been a change in judicial attitude toward enforcement. First, consider the use of liquidation clauses in the model of a negotiated contract. Both contracting parties often wish to control their risk exposure, and permitting them to do so encourages risk-taking. The performing party ${ }^{9}$ may also wish to avoid the feared irrationality of the judicial process in determining actual damages. He may also be fearful that the court will give insufficient consideration to legitinate excuses for nonperformance, that the court may be unduly sympathetic to plaintiff's claim that any loss he incurred should be paid for by the party whose nonperformance caused the loss, or that the court may consider contract breach an inmoral act.

There are also reasons why the nonperforming party as well may wish to use a liquidated damages clause. Sometimes a breach will cause daunage, but the amount of dainages cannot be proven under dainage rules. For exaunple, in wartime procurement contracts it may be impossible to establish the dannages caused by delayed or defective performance by the contractor. Without an enforceable clause purporting to liquidate damages, the nonperforming party may fear that the performing party will have insufficient incentive to perform if the latter realizes that dainages he has caused are not sufficiently provable to be collected. Such a clause is a penalty in that its principal func-

App. 3d 651, 94 Cal. Rptr. 216 (1st Dist. 1971); Bauer v. Jackson, 15 Cal. App. 3d 358, 93 Cal. Rptr. 43 (4th Dist. 1971).

8. See, e.g., CAL. CTV. CODE $\$ \S 1801$ et seq. (West 1970) (retail installment sales); id. \$\$ 1812.50 et seq. (dance studio contracts); id. \$\$ 1812.80 (health studio contracts); id. $\$ \S 1725$ et seq. (swimming pool construction); id. $\$ \$ 1718-19$ (credit cards); CaI. ANN. Bus. \& Prof. CODE $\$ \S 22250$ et seq. (West 1964) (television and radio repairs); id. $\$ 9842$ (electronic repairs).

9. In a sense each party to a contract is a "performing party," but in this discussion "performing party" means the party whose failure to perform is the basis of invoking the liquidated damages clause. Usually the performing party agrees to transfer ownership or possession or to render services in exchange for money, but sometimes the performing party promises to pay money, such as in a loan or lease. 
tion is to coerce performance. Yet if it is reasonable-not disproportionate to actual, although unprovable, damages or to the contract price-it will be enforced. ${ }^{10}$ Without a liquidated damages clause there is also a danger the contractor may recover the full contract price despite a breach that caused some unprovable losses. Thus while the nonperforming party may be motivated principally by the penalty aspects of the clause, he may to a lesser degree be motivated by the desire to prevent what appears to him to be unjust enrichment.

Liquidated damages clauses may also be imserted to improve upon what the parties believe to be a deficiency in the litigation process: the cost and difficulty of judicially proving damages. Through a liquidation clause the parties attempt to use contract to settle the amount of damages involved and thus improve the normal rules of damages. ${ }^{11}$ Also, when the clause is phrased in such a way as to indicate that the breaching party will pay a specified amount if a particular breach occurs, troublesome problems involved in proving causation and foreseeability may be avoided. This was extremely helpful, for example, in wartime procurement contracts, where not only was it almost impossible to establish the amount of damages, but it was equally impossible to establish that delayed or defective perfornnance by the contractor caused any particular loss and that the loss was reasonably foreseeable at the time the contract was inade. ${ }^{12}$ Finally, the parties may feel that if they truly agree on damages in advance, it is unlikely that either would later dispute the amount of damages recoverable as the result of his breach.

In the adhesion contract situation there are some similarities in objectives; the desire to control the irrationality and expense of the litigation process and the need to know the extent of risk exposure are still involved. There are, however, obvious additional objectives of the stronger party. He can dictate the terms of the contract; if he is the performing party, he is likely to use the contract clause to limit his exposure almost to the vamishing point, and if he is the nonperforming party, he inay try to use a penalty clause to coerce perforinance, or he may try to use a genume liquidation clause to make vindication of his legal rights as convenient and imexpensive as possible. In the adhesion context, then, the stronger party may try to limit his own hability and to set an agreed amount that is sufficiently high to coerce performance. In the event performance is not rendered, the clause may obtain a settlement or win the case.

10. See, e.g., United States v. Bethlehem Steel Co., 205 U.S. 105 (1907).

11. See Garden State Plaza Corp. v. S.S. Kresge Co., 78 N.J. Super. 485, 189 A.2d 448 (App. Div. 1963); 1 J. WigMORE, EVIDENCE $§ 7$ a (3d ed. 1940).

12. See United States v. Bethlehem Steel Co., 205 U.S. 105 (1907). 


\section{B. Judicial Responses to Liquidated Damages Provisions}

Moving froin the reasons why liquidated damages clauses are used by the parties, let us consider what motivates courts to uphold or reject these clauses. Some courts undoubtedly are persuaded by the argument that the parties have paid their money and taken their chances. ${ }^{13}$ Since the parties have assumed certain risks, courts often see no particular reason to reheve thein from the risks they have taken. ${ }^{14}$ Treating the hquidated damages clauses as any other, such courts uphold the clauses to reward the party who has guessed best on the question of damages. Other courts enforce these clauses because they beheve that protecting the reasonable expectations of the contracting parties encourages risk-taking and assists in planning. ${ }^{15}$ Still other courts look at the contract as a package and enforce the liquidation clause because they feel that the party attacking the clause has received benefits under the contract. This is especially likely when such a clause is directly related to the contract price. For example, in one important case, ${ }^{16}$ a gun manufacturer offered to supply guns at different prices depending upon when dehivery had to be made. The government chose the quickest delivery at the highest price. Nonenforcement of the delay-damage liquidation clause in this case would have disturbed the package arrangement and created unjust enrichment.

Courts also enforce these clauses because they beheve hiquidated damages clauses help the courts achieve just results. Sometimes the computation of damages in litigation is no better than a guess; as long as the amount selected by the parties is within a reasonable range, the courts feel that enforcing the amount selected is likely to be as fair as any amount determined by the court. Furthermore, courts believe that if such agreements are enforced, at least in theory the use of such clauses should expand, resulting in fewer breaches, fewer law suits, fewer or easier trials, and in many cases, at least as just a result. ${ }^{17}$

13. See 5 A. Corbin, Corbin on Contracts $\S 1060$ (1964) [hereinafter cited as CoRBIN].

14. See Southwest Eng'r Co. v. United States, 341 F.2d 998 (8th Cir. 1965); Broderick Wood Prods. Co. v. United States, 195 F.2d 433 (10th Cir. 1952); Streeter v. Rush, 25 Cal. 67 (1864). It is interesting to note that this hard attitude is most often reflected in government procurement contract cases. Undoubtedly, some of this is traceable to the feeling that government contractors should know what they are doing and can take care of themselves. See also Bethlehem Steel Corp. v. City of Chicago, 350 F.2d 649 (7th Cir. 1965).

15. See Better Foods Mkts. Inc. v. American Dist. Tel. Co., 40 Cal. $2 d$ 179, 253 P.2d 10 (1953); Fleischer v. Cosgrove, 145 Cal. App. 2d 14, 301 P.2d 911 (1st Dist. 1956). See also Bailey v. Manufacturers' Lumber Co., 224 F. 806 (S.D.N.Y. 1915).

16. United States v. Bethlehem Steel Co., 205 U.S. 105 (1907).

17. Cf. 5 CoRBIN $\S 1057$. 
Finally, courts recognize that enforcement of these clauses can cure defects in the litigation process. For example, the requirements as to certainty may seem too restrictive. A court may enforce a liquidation clause to ensure that a party will get a just recovery that might otherwise be denied him because he cannot establish the loss with sufficient certainty.

Many purported liquidated damages clauses, however, are not enforced. The traditional rationale for nonenforcement is that courts will not aid in coercion, oppression, ${ }^{18}$ or unjust enrichment; ${ }^{19}$ courts seek only to compensate, and enforcement of penalty clauses is contrary to that purpose. ${ }^{20}$ Thus, enforcement of a clause not based upon an estimate of proper compensation would cause an unconscionable result. ${ }^{21}$

Refusal to enforce these clauses may recognize the protection contracting parties need from their own unfortunate optimism and their failure to consider im advance the possibility that subsequent events may affect their perfornance. ${ }^{22}$ Like the doctrines of consideration, frustration, impossibility, and mistake, not enforcing a liquidation clause reflects the idea that the performing party should not be held strictly to his promise. The refusal to enforce a hiquidation clause does not preclude the plaintiff from recovering actual damages. This method of relieving a party from his contractual promise gives the judge the comfortable feeling that he is not upsetting traditional law but merely putting the plaintiff to his proof of damages. Courts have therefore employed nonenforcement as an equitable compromise and corrective device in various situations, such as where the performing party had a good, but not legally sufficient, case for reformation, ${ }^{23}$ where a party's delay should have been excused, ${ }^{24}$ and where the legahty of the contract was doubtful. ${ }^{25}$

Moreover, modern courts are beginning to look at the realities of the contractmaking process. They realize that if the clause is part of an adhesion contract, some of the reasons for permitting and encouraging party autonomy do not apply. When one party is under great compulsion and has no choice, it is not likely that the amount is fair risk assumption. Party autonomy is less attractive in such a context, espe-

18. See Mente \& Co. v. Fresno Compress \& Whse. Co., 113 Cal. App. 325, 298 P. 126 (4th Dist. 1931) (goods transaction).

19. See Muldoon v. Lynch, 66 Cal. 536, 6 P. 417 (1885).

20. See id.

21. See Escondido Oil and Dev. Co. v. Glaser, 144 Cal. 494, 77 P. 1040 (1904).

22. See C. McCormick, DAMAges $\S 147$ (1935) [hereinafter cited as McCorMrck].

23. Eva v. McMahon, 77 Cal. 467, 19 P. 872 (1888).

24. Muldoon v. Lynch, 66 Cal. 536, 6 P. 417 (1885).

25. Pacific Factor Co. v. Adler, 90 Cal. 110, 27 P. 36 (1891). 
cially when enforcing the clause would do violence to a damages rule that the court believes to be salutary. ${ }^{20}$ In the famous Henningsen $v$. Bloomfield Motors, Inc. case, ${ }^{27}$ for example, the court noted that to enforce the warranty clause would frustrate what the court had just announced as an advanced and modern principle of manufacturer's liability for defective products.

\section{II}

\section{Types of Contractual Clauses Controlling Damages}

\section{A. Genuine Liquidated Damages Clauses}

A liquidated damages clause can take varying shapes. In its simplest form, it may specify that for a particular breach the breaching party will pay a designated lump sum. The clause may provide a formula that will determine damages by an arithmetic computation. ${ }^{28}$ For example, a marketing association member might agree to pay a designated sum for every unit he sells in violation of the marketing agreement, ${ }^{29}$ a lessor who promises to make his land cultivatable might promise to pay a designated sum per acre for crops lost due to his breach, ${ }^{30}$ or a contractor might contract to pay a designated sum for each day of unexcused delay. ${ }^{31}$ Similarly, delay in delivery of goods might be liquidated by multiplying the number of days of unexcused delay by a designated percentage of the selling price of the goods, ${ }^{82}$ and if overhead is a recoverable item, a percentage of the contract or sale price might be specified as a liquidated amount. ${ }^{33}$

26. Mente \& Co. v. Fresno Compress \& Whse. Co., 113 Cal. App. 325, 298 P. 126 (4th Dist. 1931).

27. 32 N.J. 358, 161 A.2d 69 (1960).

28. A distinction must be made between a formula set forth in a contract that is part of the promised performance and a formula that is to be applied for determining damages in the event of breach. For example, a cost-type construction contract often specifies recoverable costs. This is not an attempt to liquidate; it is the promised performance. Even if the clause went further and stated that the contractor could recover a designated percentage of his administrative overlead as part of an allowable cost, it would still not be a liquidated damages clause. But suppose the contract were for a fixed price and the owner unjustifiably termmated it. A clause specifying that in the event of breach the contractor would be able to recover a designated percentage of the construction contract or of the contractor's overall administrative overhead in computing his cost of part performance is a clause attempting to liquidate damages.

29. See, e.g., Anaheim Citrus Fruit Ass'n v. Yeoman, 51 Cal. App. 759, 197 P. 959 (2d Dist. 1921).

30. See, e.g., Seid Pak Sing v. Barker, 197 Cal. 321, 240 P. 765 (1925).

31. See, e.g., Peter Kiewit Son's Co. v. Pasadena City Junior College Dist., 59 Cal. 2d 241, 379 P.2d 18, 28 Cal. Rptr. 714 (1963).

32. See, e.g., Broderick Wood Prods. Co. v. United States, 195 F.2d 433 (10th Cir. 1952).

33. See, e.g., Challenge-Cook Bros. Inc. v. Lantz, 256 Cal. App. 2d 536, 64 
Other liquidated damages clauses are attempts to refine the applicable legal standards for measuring damages. For example, suppose a contract specifies that, if the performing artists do not perform a concert as promised, they will pay all the expenses imcurred by the promoter in advertising the concert. If the promoters souglit recovery of their expenses in part performance, they could recover the advertising expenses rendered valueless by the breach. To do this they must show the expenditures were foreseeable by the defaulting performers at the time the contract was made and that the amount of expenditures was reasonable. ${ }^{34}$ The clause specifying that these amounts would be recoverable would materially assist the promoters, because it would get them by the foreseeability question and miglit very well foreclose any showing that the expenditures were not reasonable.

A distinction is frequently made between underliquidation and overliquidation clauses: underliquidation occurs when actual damages are substantially greater than the liquidated amount, ${ }^{35}$ while overliquidation occurs when actual damages are substantially less than the liquidated damages. On the whole, courts are less reluctant to enforce underliquidation clauses than overliquidation clauses. Awarding liquidated damages that a court believes to be substantially in excess of actual damages violates the compensation principle, but permitting underliquidation is similar to other legal doctrines that relieve performing parties, such as impossibility, frustration, mistake, and foreseeability. Sucl rehef should encourage contractmaking by protecting enterprises from inordinate risk exposure. Enforcement of underliquidation is less desirable in the personal injury area because it may disturb the rational allocation of loss distribution provided by tort law. Also, im the consumer area underliquidation can frustrate reasonable expectations and give too mucli power to the dominant contracting party. ${ }^{36}$

\section{B. Agreed Valuations}

It is common to set agreed valuations for corporate acquisitions or buy-out provisions in partnership agreements. Like a formula for determining costs, such a provision for an agreed valuation should not be subject to requirements specified for liquidated damages. Suppose, lowever, a landlord and tenant agree on valuations for certain items of

Cal. Rptr. 239 (1st Dist. 1967). But see Rice v. Schmid, 18 Cal. 2d 382, 115 P.2d 498 (1941).

34. Recovery of expenditures made in part performance would be subject to the performing party's being able to prove the losses would have resulted even if the concert had taken place. See generally RESTATEMENT OF ConTRACTS $\$ 333$ (d) (1932).

35. See generally Fritz, Underliquidated Damages as Limitation of Liability, 33 Texas L. Rev. 196 (1954). (1960).

36. See, e.g., Henningsen v. Bloomfield Motors, Inc., 32 N.J. 358, 161 A.2d 69 
personal property in the lease of an expensive house, so the damages will be fixed in the event these items are not returned to the landlord upon termination of the lease. While such an agreed valuation might be an alternative performance-the tenant can either return the designated personal property or pay the agreed valuation-in most cases agreed valuations of this type are an attempt to control damages if the designated items are not returned. Therefore, they should be considered as liquidated damages clauses.

\section{Penalty}

A penalty is a clause designed to coerce performance rather than to estimate damages. Its enforcement would be punitive in nature and would violate the compensation principle. This principle seeks to give the plaimtiff what the defendant's breach has cost him and not put the plaimtiff in a better position than he would have been in had there been proper performance. Therefore, penalties in the contract context are not supposed to be enforced.

However, nonenforcement of a penalty has caused some confusion. Even if a clause is a penalty and will not be enforced as such, it can have some operative effect. For example, a penal bond generally limits the liability of the person making the promise. Suppose a surety gives a bond for $\$ 10,000$, and it is determined that the amount is a penalty. If actual damages exceed $\$ 10,000$ the surety's obligation is limited to the designated amount. ${ }^{37}$ Or, suppose a party promising performance puts up a deposit. If the amount is a penalty, the person retaining the security must return any amount in excess of actual damages. But, the transfer of the deposit is valid in that a garnishing creditor of the depositor would not be entitled to it until its function no longer exists, and then only to the extent the deposit exceeds actual damages. ${ }^{38}$

\section{Limitation of Liability}

Increasingly, performing parties desire to limit the scope of their risk. There are numerous ways to seek to accomplish this. They may give themselves contractual protection by providing clauses that reheve them if certam events occur, by excluding warranties, by specify-

37. See Los Angeles O.G. Ass'n v. Pacific Sur. Co., 24 Cal. App. 95, 140 P. 295 (2d Dist. 1914); 5 CORBIN $\$ 1056$.

38. While there are no cases precisely on this point, in County of Los Angeles v. Margulis, 6 Cal. App. 2d 57, 44 P.2d 608 (2d Dist. 1935), and Weinreich Estate Co. v. A.J. Johnston Co., 28 Cal. App. 144, 151 P. 667 (3d Dist. 1915), the dcfendants seemed to assert that the bonds were not valid beeause they were penalties. The bonds were held operative as security deposits even though not valid liquidation clauses. 
ing that indirect, remote, or consequential damages will not be recoverable, or by including a clause that attempts to exculpate the performing party from responsibility.

A device closely akin to exculpation is a clause limiting liability to a specified, often minimal, amount. ${ }^{39}$ The plaintiff must still prove his actual damage, but the designated sum operates as a ceiling on the performing party's accountability. The important distinction between a liability limitation and liquidation of damages is that, in the former case, there is no attempt to estimate damages while there is, at least in theory, in the latter case. Also, the presence of a limitation-of-liability clause does not relieve the nonperforming party from establishing actual damages. However, courts that may be hesitant to enforce liability limitations because of what they conceive to be public policy sometimes classify such clauses as liquidation of damages. ${ }^{40}$ For the same reason, drafters sometimes choose the liquidated damages label when they are fearful of liability-limitation enforcement. ${ }^{41}$

\section{E. Security Deposits}

Security deposits are amounts paid in advance by a performing party to secure the other party in the event of nonperformance by supplying a fund out of which the nonbreaching party can satisfy his actual damages. They are cominonly used in purchases of real property, leases, and competitive bids. While some states permit retention of a deposit where courts would not enforce a promise to pay, ${ }^{42}$ in Califorma courts generally treat actions to recover liquidated damages and actions to recover deposits in the same manner. ${ }^{43}$

A deposit can, however, serve several functions. Obviously, if it is paid in advance, it can provide security. Furthermore, the amount designated may be an attempt to agree on damages in advance, but

39. See, e.g., Nester v. Western Union Tel. Co., 309 U.S. 582 (1940); Better Foods Mkts., Inc. v. American Dist. Tel. Co., 40 Cal. 2d 179, 253 P.2d 10 (1953); Bauer v. Jackson, 15 Cal. App. 3d 358, 93 Cal. Rptr. 43 (4th Dist. 1971).

40. See Better Foods Mkts., Inc. v. American Dist. Tel. Co., 40 Cal. 2d 179, 253 P.2d 10 (1953).

41. See id.

42. See Beatty v. Flannery, 49 So. 2d 81 (Fla. 1950), criticized in Note, Liquidated-Damages Clauses in Real Estate Contracts, 4 U. FLA. L. REv. 229 (1951). But in Hutchison v. Toinpkins, 240 So. 2d 180 (Fla. App. 1970), a defaulting buyer was given a defense when he persuaded the escrow agent to return the deposit to him, the court distinguishing Beatty as a deposit made to the seller directly. In view of the frequent use of escrow agents, it is likely that the next case in which a deposit is made to the seller will overrule Beatty.

43. See, e.g., Freedman v. Rector, 37 Cal. 2d 16, 230 P.2d 629 (1951). McCorMrCK $\$ 153$ states that the making of the deposit usually is an indication that the amount is not disproportionate. Buyers are likely to think twice before putting up hard cash. For this reason, and because the law hesitates to interfere with possession, deposits are less likely to be recoverable than are promises to pay to be enforced. 
because the security deposit commonly can apply to a variety of types of breaches, it is difficult to classify it as genuine liquidated damages.

\section{F. Alternative Performances}

Sometimes a performing party can discharge his obligation to perform in several ways. For example, a farmer who purchases 160 acres of land may promise either to cultivate the acreage and pay the seller a percentage of the money he receives from the sale of crops, or if he does not cultivate the acreage, to convey a designated piece of land to the seller. These may be alternative performances. If so, the farmer can either cultivate the 160 acres or convey the designated land. Alternative performances can also be a promise to perform or pay a designated sum of money, as when the seller of a small business promises that he will either not compete for a period of time or he will pay the buyer of his business a percentage of any profits he makes if he does compete.

Like most alternative performances, both these situations are ambiguous; they could be alternative performances or they could be devices for avoiding limitations on penalty clauses. Even more difficult problems of classification can arise. For example, suppose the buyer of a large machine wishes dehivery on January 1 and is willing to pay $\$ 1,000,000$ for delivery on that date. The contract specifies that the delivery date will be February 1 and the contract price $\$ 900,000$, but if the seller delivers the machine by January 1 , he will obtain a bonus of $\$ 100,000$. If these are found to be genuine alternative performances, the seller can perform by delivery on either January 1 or February 1 , and the time of delivery determines the amount he is to receive for the machine. If, however, the antecedent negotiations demonstrate that the final form of the contract is an attempt to hide a $\$ 100,000$ penalty for a 30-day delay, a court is likely to loold this a penalty and that the seller is entitled to $\$ 1,000,000$ less actual damages if he delivers February 1. Because of its ambiguity, the alternative performances device has been a method frequently used by courts to enforce clauses that they believed they could not enforce as liquidation of damages provisions.

\section{III}

\section{The California Cases}

California liquidated damages law is controlled by two sections of the Civil Code. Section $1670^{44}$ provides:

Every contract by which the amount of damage to be paid, or other compensation to be made, for a breach of an obligation, is

44. CaL. Civ. COde $\$ 1670$ (West 1970). 
determined in anticipation thereof, is to that extent void, except as expressly provided in the next section.

The next section ${ }^{45}$ provides:

The parties to a contract nay agree therein upon an amount which shall be presumed to be the amount of damage sustained by a breach thereof, when, froin the nature of the case, it would be impracticable or extremely difficult to fix the actual damage.

While they are phrased in general terms, their application has in fact varied significantly depending on the type of contract involved. Because of this, an analysis of the courts' activities can best be accomplished by separately considering the various specific types of contracts that have employed liquidation clauses.

\section{A. Land Transactions}

For 20 years there has been a constant struggle between the courts and sellers of land relating to the right of a seller to retain deposits made by a buyer if the buyer defaults. Damage liquidation has been one theory sellers have frequently used in their constantly shifting attempts to employ contract language that will make it possible to retain deposits without the necessity of proving actual damages. The struggle has already been well chromicled, ${ }^{46}$ but a brief summary is necessary for understanding the role damage liquidation has played in the land contract deposit cases.

Ordinarily the purchase of land is a two-step transaction. The first is the contract to purchase; in California this contract is usually expressed in a document called the "Deposit Receipt" and is accompanied by a cash deposit. The second is the exchange of the balance of the purchase price for the deed.

Suppose the excliange is not made because of default by the buyer. He has committed a breach unless he has conditioned his obligation upon the occurrence of events that did not occur and are not excused. Despite his breach, lowever, sometimes the buyer will subsequently seek to revive his contract rights. Whether he can do so depends upon the language of the contract to purchase and various doctrines derived froin long-term purchase transactions that may relieve him from forfeiture. ${ }^{47}$ Alternatively, the buyer may seek to recover

45. CaL. Crv. CoDE $\S 1671$ (West 1970).

46. Alexander, Liquidated Damages Again-A New Synthesis, 41 L.A.B. BuLL. 419 (1966); Hetland, The California Land Contract, 48 CaLIF. L. REv. 729 (1960); Smith, Contractual Controls of Damages in Commercial Transactions, 12 HastnNGs L.J. 122 (1960); Comment, 35 S. CAI. L. Rev. 301 (1962).

47. See CAL. Crv. Code $\$ \$ 1492,3275$ (West 1970). See also MacFadden v. Walker, 5 Cal. 3d 809, 488 P.2d 1353, 97 Cal. Rptr. 537 (1971). 
his deposit. It is here that damage liquidation has been important; sellers have used contract-specified remedies to justify retention of the downpayment without having to show the actual damages that resulted from the breach.

To understand the cases it is important to review briefly the various remedies the seller has when the buyer defaults. First, he has a right to specific performance, but since the buyer's default usually relates to inability to obtain financing, this remedy is not often practical. Another course open to the seller is to sue for damages. The damages he will seek are of two types: general and special. General damages are those that are usual and flow directly from the breach, while special damages are those that may have been caused by the breach but are not usual or foreseeable. Generally, damages are governed by section $3307,,^{48}$ which establishes the measure of recovery for direct damages as the difference between contract and market price at the time of breach. ${ }^{49}$ However, section 3307 does not set the exclusive remedy, and a number of recent cases have allowed the seller also to recover special dainages. ${ }^{50}$

The seller, however, would like to retain the deposit without the costliness and difficulty of showing damages, even if both general and special dainages are recoverable. Sellers have therefore sought to estabhish damages contractually. Judicial treatment of these attempts has varied. An early case permitted the defaulting purchaser to recover his deposit to the extent it exceeded actual damages, ${ }^{, 1}$ but Glock $v$. Howard ${ }^{\text {,2 }}$ decided in 1898 , held that the defaulting purchaser could not recover his deposit, and this case becane the established law. Then, between 1949 and 1951 the supreme court, applying section $3275,{ }^{63}$ granted relief from forfeiture to nonwillfully defaulting buyers. ${ }^{64}$

48. CaL. Crv. CoDE $\$ 3307$ (West 1970).

49. See Royer v. Carter, 37 Cal. 2d 544, 233 P.2d 539 (1951).

50. See id.; Jensen v. Dalton, 9 Cal. App. 3d 654, 88 Cal. Rptr. 426 (1st Dist. 1970) (cost of additional resale commission, added taxes and assessments, commuting expenses for second home, all recoverable); Sutter v. Madrin, 269 Cal. App. 2d 161, 74 Cal. Rptr. 627 (2d Dist. 1969) (vendor allowed an interim expense to offset vendee's claim for restitution). But see Allen v. Enomoto, 228 Cal. App. 2d 798, 39 Cal. Rptr. 815 (1st Dist. 1964) (allowing only expenses incurred in accepting home as payment, refinancing expenses, and title insurance premiums).

51. Drew v. Pedlar, 87 Cal. 443, 25 P. 749 (1891).

52. 123 Cal. 1, 55 P. 713 (1898).

53. Cal. CTv. CoDe $\$ 3275$ (West 1970):

Whenever by the terms of an obligation, a party thereto incurs a forfeiture, or a loss in the nature of a forfeiture, by reason of his failure to comply with its provisions, he may be relieved therefrom, upon making full compensation to the other party, except in case of a grossly negligent, willful, or fraudulent breach of duty.

54. Baffa v. Johnson, 35 Cal. 2d 36, 216 P.2d 13 (1950); Barkis v. Scott, 34

Cal. 2d 116, 208 P.2d 367 (1949). 
In 1951 the supreme court extended this protection to a willfully defaulting buyer in Freedman v. Rector. ${ }^{55}$ There the buyer was permitted to recover his $\$ 2,000$ deposit because he established that shortly after breach the seller had sold the property for $\$ 2,000$ more than the contract price. Since the default was willful and section 3275 thus unavailable, the court relied upon principles of unjust enrichment. To enforce the contract clause permitting the seller to retain the downpayment in these circumstances, the court argued, would violate the statutory prohibition against awarding punitive damages for breach of contract. ${ }^{56}$ ?

Thus, the court appeared to reverse the Glock rule and put California in the camp of those progressive states that permit defaulting plaintiffs under any type of contract to recover the net benefit they have conferred on the other party. ${ }^{57}$ The court then went on to discuss briefly the applicability of California's liquidation legislation, sections 1670 and 1671. It first said that forfeiture clauses in land sales are "presumptively valid" if the downpayment is reasonable in amount.58 The court then held that actual damages in this case were not impracticable or difficult to fix, apparently because the subsequent sale was considered to have established the extent of actual damages.

The Freedman case caused many attorneys to fear that the liquidation of damages approach was unavailable as a device to justify retention of downpayments in California land transactions. Evidently, the belief was that section 3307 gave a remedy that was sufficient and thus precluded the use of section 1671. The bar therefore attempted to justify retention of the deposits through fictional recitals of various types, such as declarations that the deposits were "earned consideration" or "separate consideration for entering imto the contract." These, however, were unsuccessful. The separate-consideration recital failed in Rodriguez $v$. Barnett ${ }^{59}$ a case where the buyer was excused because an event that conditioned his obligation to perform did not occur. The recital was held insufficient to avoid the unjust enrichment concept, so the buyer recovered his payment despite a clause permitting the seller to retain it. The recital of consideration for entering into the contract proved unsuccessful a few years later in Caplan $v$. Schroeder. ${ }^{60}$ The Caplan case, however, was not a total loss for

\footnotetext{
55. 37 Cal. 2d 16, 230 P.2d 629 (1951).

56. Id. at 21,230 P.2d at 632 .

57. See 5A Corbin $\$ 1129$.

58. $37 \mathrm{Cal} .2 \mathrm{~d}$ at $23,230 \mathrm{P} .2 \mathrm{~d}$ at 633 .

59. 52 Cal. 2d 154, 338 P.2d 907 (1959).

60. 56 Cal. 2d 515, 364 P.2d 321, 15 Cal. Rptr. 145 (1961).
} 
sellers, because in Caplan the court seemingly invited sellers to use section 1671 as a means of retaining the deposit through a suggestion that the seller would have been permitted to retain the deposit in Caplan liad he relied upon section 1671 rather than the consideration-forentering-the-contract fiction.

The supreme court's "invitation" and the option approach have resulted in confused and conflicting lower court decisions. In Greenbach Brothers, Inc. v. Burns, ${ }^{61}$ a seller had to return the deposit despite a clause that seemed to comply with section 1671 . While the court of appeal seemed doubtful that danages were difficult to ascertain, it relied on other grounds:

We see nothing in the record before us to indicate that the parties here made any effort to estimate the actual damages that might be suffered by appellant in the event of respondent's breach. ... . On this state of the record the trial judge could reasonably conclude that the amount of each deposit was arbitrarily arrived at and was not intended to represent damages. . . . ${ }^{62}$

Because the court felt a reasonable attempt to estimate damages is essential to comply with section 1671 , the court held for the buyer.

The difficulty with this case is that, as noted by Professor Hetland, ${ }^{63}$ the seller, probably out of an abundance of caution to protect his right to the deposit, gave up his right to specific performance. This, says Professor Hetland, shows that an option was actually created and, if there is an imeffective attempt to liquidate damages, the Freedman concept applies. This was recognized by the court in Welk $v$. Fainbarg. ${ }^{64}$ There was some confusion in that case because one document referred to the $\$ 20,000$ paid by the buyer as having been paid for an option, while another document referred to it as an advance payment of liquidation damages. Consequently, the court had to resolve whether an option or a bilateral contract was created from the negotiations. The court looked to whether the seller could obtain specific performance from the buyer and, concluding that he could not, held it was an option. Thus, the seller could retain the $\$ 20,000$. Had this rationale been applied in Greenbach, the seller there would also have been able to retain the deposit.

This type of confusion is avoided in most states through the "earnest money" concept, a simple, direct approach that accomphishes the

61. 245 Cal. App. 2d 767, 54 Cal. Rptr. 143 (1st Dist. 1966).

62. Id. at 772, 54 Cal. Rptr. at 147.

63. J. Hetland, California Real Estate Secured Transactions $\$ 3.50$ (1970).

64. 255 Cal. App. 2d 269, 63 Cal. Rptr. 127 (4th Disst. 1967). 
necessary purpose. The down payment given at the time the contract to purchase land is made is deemed "earnest money" paid to show that the buyer is "in earnest," that he is serious about the transaction. The payment also shows that the prospective buyer at least has the ability to put up some money, indicating that he is likely to obtain the rcst of the money and complete the transaction. Normally, a reasonable earnest money payment is retained by the seller if the buyer defaults. ${ }^{05}$

This approach unfortunately seems precluded in California by the Freedman and Caplan cases, and no adequate substitute has been found. Recitals that the deposit is earned consideration or separate consideration for entering into the transaction were held insufficient to justify retention in Rodriguez and Caplan. ${ }^{66}$ If an option were really created, it is likely that the seller could retain the deposit were the buyer not to exercise the option. But the parties and courts typically think a bilateral contract is created, not an option. ${ }^{67}$

The validity of the use of a deposit as hquidated damages is less certain. The Caplan opinion seems to invite this approach and the most recently drafted standard deposit receipt form uses it. ${ }^{68}$ The principal difficulty in enforcing the clause as a true hquidation lies in the failure to comply with the test of McCarthy $v$. Tally; ${ }^{69}$ it is not likely that the anount deposited is determined as a reasonable estimation of potential damage. Rather, it is usually a flat ainount or a percentage of the contract price. An illustration of this can be seen in the case of Major-Blakeney Corp. v. Jenkins. ${ }^{70}$ In this case there were two transactions between the same buyer and seller, one for a contract price of $\$ 6,700$ and one for a contract price of $\$ 56,275$. The deposit in the smaller contract was for $\$ 1,500$ and in the larger contract, $\$ 1,000$, almost certain proof that these amounts were not selected as estimations of the damage that would result if the buyer breached. Furthernore, even if there were a genuine estimation of damages, the difficulty-of-ascertainment test, which usually precludes liquidation where the ainount of damages is not difficult to establish, ${ }^{71}$ might preclude enforcement of the liquidation clause.

65. See Restatement of CoNTracts $\$ 357(2)$ (1932).

66. But see Folden v. Lobrovich, 171 Cal. App. 2d 627, 341 P.2d 368 (1st Dist. 1959) (a pre-Caplan case).

67. See Hetland, supra note 46 , at 743.

68. See Real Estate Purchase and Receipt for Deposit, 42 CaL. ST. B.J. 487, 493 (1967).

69. 46 Cal. $2 \mathrm{~d} 577,297$ P.2d 981 (1956). See text accompanying note 252 infra.

70. 121 Cal. App. 2d 325, 263 P.2d 655 (2d Dist. 1953).

71. See text accompanying notes 229-51 infra. 
One way that some have suggested of avoiding these difficulties is to include recitals of potential special damages. ${ }^{72}$ One can visualize attorneys creating artful declarations of lost opportunities to sell at a higher price between time of contract and breach, unusual profits, incurring expense of maintaining two houses when the seller has relied and purchased another house, immense brokerage commissions, and so forth. While a number of recent cases have broadened the scope of recovering special damages, ${ }^{73}$ it is unlikely that courts will exalt form over substance and hold that these recitals of potential special damages inake a retention clause valid.

What is needed is a new approach that would respect sellers' and buyers' intentions on this question in the absence of extreme inequality of bargaining power or an unreasonable stipulated amount. The parties ought to know where they stand at the time the contract is made and not be left to the uncertainty of the law in this area. Generally, sellers expect to retain the downpayment without any need to show actual damages; buyers think that their exposure is limited to the amount of the deposit. There have been a number of cases where the expectation of the buyer as well as that of the seller las been frustrated. ${ }^{74}$ As long as the amount seems reasonable to the court and the parties knew what they were domg, there is no reason to interfere with their autonomy. In short, what is needed is a simple formula $^{75}$ that will enable the seller to keep the deposit or some designated lesser amount without regard to actual damages. This could most simply be accomplished if California returned to the earnest money concept. That approach would provide a proper solution for cases involving either a defaulting buyer or a buyer who agrees to forfeit his deposit even if events occur that could terminate his obligation to purchase.

\section{B. Leases of Real and Personal Property}

Leases have played an important part in the California law relating to liquidated damages; until the advent of the land contract cases, they composed the bulk of California liquidation of damages decisions. Most concerned the right of a landlord to retain advance deposits upon a tenant breach, without regard to actual damages. The issues in these cases are similar to those discussed in the land cases, but, at least prior

72. E.g., Alexander, supra note 46, at 420-21.

73. See note 50 supra.

74. E.g., Royer v. Carter, 37 Cal. 2d 544, 233 P.2d 539 (1951); Fleischer v. Cosgrove, 145 Cal. App. 2d 14, 301 P.2d 911 (1st Dist. 1956).

75. For a method of avoiding the uncertainty of what is reasonable, see note 293 infra. 
to the 1970 legislation, the issues were resolved quite differently from the land deposit cases.

While most lease cases did not involve true liquidations, they are instructive for a number of reasons: First, they reflect the continued tension between the concepts of party autonomy and unjust enricliment. Also, they demonstrate the intense preoccupation of lawyers and judges with lease language as a means of establishing and determining the validity of liquidation clauses; this contrasts with the modern tendency to look through the language of the contract to determine the clause's validity in terms of its function. Finally, the lease cases demonstrate how half-truths have permeated this area of law; instead of looking at the different types of contract breaclies incident to a lease, there has been an unfortunate tendency to take the typical lease cases, which involve attempts to retain deposits, and postulate a general rule that liquidation of damages is not permitted in lease transactions.

Even though the results of many of the cases involving advance payments have becoine irrelevant due to the legislation in $1970,{ }^{76}$ the principal issues that arose prior to this legislation generally remain. A number of cases established the basic rule that a landlord could retain an advance payment if it was found to be prepayment of rent, or a bonus or consideration for execution of the lease. ${ }^{77}$ Often, in determining this issue, courts refused to look beyond the language of the lease. ${ }^{78}$

Some courts, however, have been more helpful to lessees. For example, in Friedman v. Isenbruck ${ }^{79}$ the court, although recognizing the "larsh but well settled" 80 rule permitting the landlord to retain ad2452.

76. Ch. 89, $\$ \S 1-14$, [1970] Cal. Stat. 104-07; ch. 1317, § 1, [1970] Cal. Stat.

77. See Warming v. Shapiro, 118 Cal. App. 2d 72, 257 P.2d 74 (1st Dist. 1953) (bonus); Ace Realty Co. v. Friedman, 106 Cal. App. 2d 805, 236 P.2d 174 (2d Dist. 1951) (prepaid rent); Kuhlemeier v. Lack, 50 Cal. App. 2d 802, 123 P.2d 918 (2d Dist. 1942) (payment for an option to terminate); Parigian v. Citizen's Nat'l Trust \& Sav. Bank, 42 Cal. App. 2d 773, 110 P.2d 117 (2d Dist. 1941) (bonus); A-1 Garage v. Lange Inv. Co., 6 Cal. App. 2d 593, 44 P.2d 681 (1st Dist.), cert. denied, 296 U.S. 642 (1935) (bonus); Weinreich v. Vernon, 109 Cal. App. 60, 292 P. 651 (2d Dist. 1930) (prepaid rent); Wood v. Hipwill, 107 Cal. App. 680, 290 P. 1040 (4th Dist. 1930) (bonus upheld despite possibility of refund); McArthur v. Kluck, 75 Cal. App. 785, 243 P. 453 (1st Dist. 1925) (prepaid rent); Anderson v. Julius Levin Co., 71 Cal. App. 73, 234 P. 442 (1st Dist. 1925) (consideration for execution of lease) (dictum); Curtis v. Arnold, 43 Cal. App. 97, 184 P. 510 (1st Dist. 1919) (consideration for prepaid rent); Ramish v. Workman, 33 Cal. App. 19, 164 P. 26 (2d Dist. 1917) (bonus).

78. A-1 Garage v. Lange Inv. Co., 6 Cal. App. 2d 593, 44 P.2d 681 (1st Dist.), cert. denied, 296 U.S. 642 (1935); Weinreich v. Vernon, 109 Cal. App. 60, 292 P. 651 (2d Dist. 1930); Ramish v. Workman, 33 Cal. App. 19, 164 P. 26 (2d Dist. 1917).

79. 111 Cal. App. 2d 326, 244 P.2d 718 (1st Dist. 1952).

80. Id. at 335,244 P.2d at 723 . 
vance rental payments and bonuses for executing the lease, held that the prepayment provision did not preclude a partial rent refund where the premises became unusable, because under certain conditions, the rental was refundable. Other courts for various reasons have held the payments to be security deposits based upon contract provisions that might compel the landlord to return part of the deposit to the tenant. ${ }^{81}$ And in Thompson v. Swiryn ${ }^{82}$ the court held for the tenant despite bonus language because another provision of the lease gave the landlord the option of not rebuilding in the event of destruction; that, according to the court, permitted parol evidence to be admitted to aid in interpreting the intended meaning of the bonus language.

Other courts helped lessees by blurring the distinction between prepaid rent and bonus for entering into the lease. If the landlord evicts the tenant, he should not be able to keep a deposit for prepayment of rent; if, however, it is a bonus, the lease has been executed, and the tenant should have no right to recover the amount even if the landlord unjustifiably evicts him. This distinction was simply ignored in Graham v. Wood, ${ }^{83}$ a case involving a tenant's attempt to recover a deposit when the landlord defaulted. Disregarding the lease language, "inducement ... to enter into" the sublease, the court held the advance payment was a security deposit. Furthermore, the court went on to state, even were it a bonus the tenant would be entitled to recover because of the landlord's breach.

These holdings could not be avoided through damage hiquidation clauses, because they are not valid as such and advance payments would then become security deposits. This was established in Jack $v$. Sinsheimer, ${ }^{84}$ which involved a commercial lease with a provision that, if the tenant defaulted, he would pay $\$ 1,000$ as liquidated damages.

81. See Bacciocco v. Curtis, 12 Cal. 2d 109, 82 P.2d 385 (1938) (amount to be applied to end of term, interest credited to tenant and refundable if premises destroyed); Dicker v. West, 164 Cal. App. 2d 55, 330 P.2d 106 (3d Dist. 1958) (destruction by fire); Friedman v. Isenbruck, 111 Cal. App. 2d 326, 244 P.2d 718 (1st Dist. 1952); Walter H. Sullivan, Inc. v. Johnson, 116 Cal. App. 591, 3 P.2d 72 (1st Dist. 1931) (interest payable and amount applied to end of term); Rez v. Summers, 34 Cal. App. 527, 168 P. 156 (2d Dist. 1917) (returnable if premises destroyed).

82. 95 Cal. App. 2d 619, 213 P.2d 740 (4th Dist. 1950).

83. 8 Cal. App. 2d 451, 48 P.2d 124 (1st Dist. 1935). Butt v. Bertola, 110 Cal. App. 2d 128, 242 P.2d 32 (1st Dist. 1952), involved a clause that specified the advance payment was consideration for executing the lease. The landlord evicted the tenant and the court of appeals held the tenant could recover the deposit. The trial court had held for the landlord but the appellate court felt that clauses permitting the landlord to keep the deposit when he evicted the tenant were utterly repugnant. $I d$. at 136,242 P.2d at 38. Yet, if the anount is truly a bonus for making the lease, it should not be refundable even if there is an eviction. The case shows the confusion created by fictitious labels.

84. 125 Cal. 563, 58 P. 130 (1899). 
The court held the provision void as a penalty. ${ }^{85}$ In addition to the difficulty-of-ascertainment barrier, this was consistent with the well-accepted principle that because a liquidation provision accompanied by an advance payment typically applies to many breaches of differing gravity, it cannot be a reasonable endeavor to estimate damage. ${ }^{86}$

The recent enactment of chapters 89 and 1317 by the 1970 California Legislature was to reform several aspects of landlord-tenant case law that had proved undesirable. ${ }^{87}$ For purposes of this Article, the sections dealing with advance payment and liquidation of damages are most important. ${ }^{88}$

Civil Code section 1951.7(a) combines prepayments of rent, security deposits, ${ }^{89}$ and the "substantial equivalent of either"-hopefully including fictional bonuses and consideration for entering into the lease-and calls them "advance payments." The balance of the section provides that a notice of reletting must be sent to the tenant upon his request if advance payments are made and the lease is terminated by default of the tenant. The mechanism for notice is tied with section $1951.4(\mathrm{c})$, which specifies the duty to relet and the amount of benefitof-bargain damages.

The unjust enrichment problem is treated in section 1951. Subsection (a) states:

Any payment or deposit of money the primary function of which is to secure the performance of a rental agreement or any part of such agreement, other than a payment or deposit, including an advance payment of rent, made to secure the execution of a rental agreement, shall be governed by the provisions of this section.

Hopefully, the phrase "primary function" will avoid the fictional recitals of prepayment of rent or bonus for making the lease that have obscured the real function of the deposit. The exception for payments made to "secure the execution of a rental agreement" should not include a bonus to make the lease, but sliould be limited to a security deposit given to secure the execution of a lease at the time a contract to lease is made. Nor sliould it include an advance payment called a security to

85. See also Redmon v. Graham, 211 Cal. 491, 295 P. 1031 (1931) (labelled as liquidated damage but returnable if no breach or destruction); Green v. Frahm, 176 Cal. 259, 168 P. 114 (1917).

86. See Webster v. Garrette, 10 Cal. App. 2d 610, 52 P.2d 550 (3d Dist. 1935).

87. Ch. 89, §§ 1-14, [1970] Cal. Stat. 104-07; ch. 1317, § 1, [1970] Cal. Stat. 2452. See generally Harvey, A Study to Determine Whether the Rights and Duties Attendant upon the Termination of a Lease Should Be Revised, 54 CALIF. L. Rev. 1141 (1966).

88. It is, however, also noteworthy that the enactment of Civil Code section 1951.2 provided a better benefit-of-the-bargain damage remedy for the landlord when the tenant defaults in the payment of rent.

89. See generally Note, The Rental Security Deposit in California, 22 HAST. L.J. 1373 (1971) (dealing with security deposits in leases). 
enter into the lease if the amount is to be applied to the rent or is refundable for any other reason.

Subsection (d)(2) of section 1951 provides that the landlord will return any excess of the deposit over actual damages set forth in subsection (c). The legislature attempted to reverse cases that permitted the landlord to retain advance payments under the labels of prepaid rent or bonus for entering into the lease; in effect, the Freedman concept was legislatively adopted.

The 1970 legislation also enacted section 1951.5, which states that sections 1670 and 1671 , relating to liquidated damages, apply to the lease of real property. Evidently, this is designed to permit liquidation in leases where it would otherwise be proper under section 1671. Because liquidation has not worked where the breach relates to a nonpayment of rent, ${ }^{90}$ this section will only apply to other types of breaches courts have held may be liquidatable. Illustrations of liquidatable breaches include breach of convenants to return or vacate the rented property in cases where actual damages are difficult to estimate ${ }^{01}$ and breach of any covenant-including nonpayment of rent-in a lease that involves goodwill of a business. ${ }^{02}$

It may also be possible that the parties to a lease can contractually provide for benefit-of-the-bargain damages. While there have been

90. The principal difficulty in the rent liquidation is the availability of interest as an easily administrable measure of recovery. In fact, in Knight v. Marks, 183 Cal. 354, 191 P. 531 (1920), the court stated that Civil Code section 3302 sets interest as the exclusive measure of recovery for the failure to pay money. But see Reichert v. General Ins. Co. of America, 68 Cal. 2d 822, 442 P.2d 377, 69 Cal. Rptr. 321 (1968). In an earlier opinion, subsequently withdrawn, the supreme conrt had concluded that section 3302 did not set the exclusive measure of recovery. Reichert v. General Ins. Co. of America, 428 P.2d 860, 59 Cal. Rptr. 724 (Cal. 1967). On rehearing, the Reichert court held the proper party to bring the law suit was not the insured but the trustee in bankruptcy. As a result, the court did not squarely face the exclusivity of section 3302 problems. See also 68 Cal. 2d at 839, 442 P.2d at 386, 69 Cal. Rptr. at 330 (1968) (Peters, J., dissenting).

Because acceleration clauses bear no relationship to the amount of damages, they also have been refused enforcement in California on the ground that they are not genvine attempts to liquidate damages. See Ricker v. Rombough, $120 \mathrm{Cal}$. App. 2d Supp. 912, 261 P.2d 328 (Super. Ct., App. Dep't 1953); Electrical Prods. Corp. v. Williams, 117 Cal. App. 2d Supp. 813, 256 P.2d 403 (Super. Ct., App. Dep't 1953). But see La Sala v. American Sav. \& Loan Ass'n, 5 Cal. 3d 864, 489 P.2d 1113, 97 Cal. Rptr. 849 (1971) (loan acceleration upon encumbrance).

91. Compare Wilmington Trans. Co. v. O'Neil, 98 Cal. 1, 32 P. 705 (1893) and Fox Chicago Realty Corp. v. Zukor's Dresses, Inc., 50 Cal. App. 2d 129, 122 P.2d 705 (2d Dist. 1942) with Vucinich v. Gordon, 51 Cal. App. 2d 434, 124 P.2d 868 (2d Dist. 1942). But see Shady v. Mercantile Arcade Realty Co., 206 Cal. 363, 274 P. 340 (1929). See also Eva v. McMahon, 77 Cal. 467, 19 P. 872 (1888) (clause liquidating damages for lessor's failure to deliver premises not enforced because the amount was unreasonable).

92. McCarthy v. Tally, 46 Cal. 2d 577, 297 P.2d 981 (1956). 
no cases involving this issue, there is no reason why a landlord and tenant could not contractually establish this measure of damages. And, there may be good reason to do so. Suppose there is a commercial lease for 99 years, and the tenant abandons at the end of five. Under section 1951, the landlord will be entitled to benefit-of-the-bargain dainages for the remaining 94 years, but on at least one occasion a court granted damages for only a few years, arguing that the damages in the other years were too speculative. ${ }^{93}$ This could be avoided if the parties agree in advance on some amount-for example, that the difference between contract and market price will be 5 percent for the balance of the lease. In such a case, at both the time of the breach and of the trial, certainty would be a formidable obstacle. Therefore, liquidation should be permitted if the amount has a rational basis.

\section{Goods Transactions}

The general rule is that liquidation clauses are not enforceable in goods-transaction contracts. This rule is usually true whether it is the buyer's or seller's breach that is the subject of the clause. However, in order to discuss the application of the rule to specific situations, it is useful to consider buyer-breach cases separately from seller-breach cases.

\section{Seller-Breach Cases}

The leading California case on seller breaches, and the source of the general rule of nonenforceability of hquidation clauses in goods contracts, is Stark $v$. Shemada, ${ }^{94}$ decided in 1922. The contract-for the sale of used furniture and furnishings of a hotel that the buyer intended to sell at a public auction-specified a price of $\$ 1,700$ and $\mathrm{h}$ quidated damages of $\$ 500$ if the seller did not dehiver any of the goods. The buyer tried to show compliance with section 1671 by alleging that, because he intended to sell the goods at a public sale, there was no way of determining at the time the contract was made what profit he would receive. The court rejected this position:

[T] his second-hand furniture ... was an ordinary commodity of personal property to be bought and sold on the open market. It is a matter of common knowledge that second-hand household and hotel furnishings are a commodity of extensive barter and sale, with a market value, according to its condition and quality, readily ascertainable.95

The court then concluded that the controlling sections of the sales act, which stated that the buyer's measure of recovery is the difference

93. Hawkinson v. Johnston, 122 F.2d 724 (8th Cir. 1941).

94. 187 Cal. 785,204 P. 214 (1922).

95. Id. at 788, 204 P. at 215. 
between contract and market prices, established the damages. ${ }^{08}$ Only when goods are purcliased for a special purpose or have a special value is it possible to liquidate damages validly for breacli of a goods contract. The test is whether there is a reasonably convenient method of computing the damages at the time of breach or at the time of trial.

Apart from cases involving marketing cooperatives ${ }^{97}$ and one preCivil Code case, ${ }^{98}$ only in dehivery-delay breaches have liquidation clauses been enforced. ${ }^{99}$ Nonenforcement has resulted where the hquidation clause is an attempt by the buyer to guarantee himself a certain anount of damages ${ }^{100}$ or where the clause is an attempt by the seller to limit the scope of possible hability for breach of warranty. Such limitations on liability are especially likely to be lield invalid if the court believes that actual damages substantially exceed the amount specified. In Greenleaf v. Stockton Combined Harvester \& Agricultural Works, ${ }^{101}$ for example, a contract for the sale of a harvester specified that the buyer would receive a refund if the machine failed to perform properly. The court held that even if this was intended to be a hquidation clause, the statutory rules establishing damages for breach of warranty controlled, because the actual damages were neither impracticable nor difficult to ascertain.

\section{Buyer-Breach Cases}

Nineteen years after Stark established the general rule that there can be no liquidated damages in seller-breach cases, the supreme court extended the rule to buyer-breach cases in Rice $v$. Schmid. ${ }^{102}$ The seller, a wholesale flour merchant, contracted to sell 6,000 barrels of flour at a designated price per barrel. After taking approximately half of the flour, the buyer refused to accept any more. The seller attempted to enforce a standardized liquidated damages provision generally used between millers and flour buyers, ${ }^{103}$ which provided that damages would

96. Id.

97. See text accompanying notes 193-99 infra. Even this exception has been narrowly limited. See Olson v. Biola Cooperative Raisin Growers Ass'n, 33 Cal. 2d 664,204 P.2d 10 (1949) (liquidation not allowed for breach relating to quality of goods delivered to cooperative); Sun-Maid Raisin Growers v. Paul A. Mosesian \& Son, Inc., 90 Cal. App. 1, 265 P. 828 (3d Dist. 1928).

98. Fisk v. Fowler, $10 \mathrm{Cal} .512$ (1858).

99. See Consolidated Lumber Co. v. City of Los Angeles, 33 Cal. App. 698, 166 P. 385 (2d Cir. 1917); cf. Byron Jackson Co. v. United States, 35 F. Supp. 665 (S.D. Cal. 1940) (applying the federal common law).

100. Pacific Factor Co. v. Adler, 90 Cal. 110, 27 P. 36 (1891); Sun-Maid Raisin Growers v. Paul A. Mosesian \& Son, Inc., 90 Cal. App. 1, 205 P. 828 (3d Dist. 1928). 101. 79 Cal. 606, 21 P. 369 (1889).

102. 18 Cal. 2d 382, 115 P.2d 498 (1941).

103. The provision had been upheld in cases in other states. See Rice v. Schmid, 108 P.2d 68, 71-72 (Cal. App. 2d Dist.) rev'd, 18 Cal. 2d 382, 115 P.2d 498 (1941). 
be the sum of three items: a carrying charge, determined by multiplying the unaccepted barrels of flour by a specified amount based upon the time from the date of the contract to the date of termination; a fixed amount per barrel as the cost of sales; and the difference in market price of wheat at the time of contracting and the date of termination times the number of bushels of wheat needed to manufacture one barrel of flour. Applying the liquidated damages clause would have resulted in damages of approximately $\$ 13,000$. The supreme court, disagreeing with both the trial court and the court of appeals, held the liquidation of damages clause mvalid on the basis of section 1671 and Stark. ${ }^{104}$ The court noted that the absence of an organized market excliange for the sale of flour or price quotations published in newspapers did not mean the damages were difficult to ascertain, since there were price quotations for the sale of flour. This precluded liquidation. The court further held the measure of damages to be the difference between the contract price of flour and the market price at the time of breach, not lost profit. ${ }^{105}$

Rice established that nonacceptance of most goods, like nondelivery, is not a liquidatable breach, because there is a clear, well-known, easily administerable measure of recovery. Only where there is a true special damages situation is there the need to permit the parties autonomy to fix the amount of damages in advance. ${ }^{106}$ This rule has been applied to invalidate almost every type of liquidation clause in the buyer-breach situation, both those that simply attempt to establish damages at a fixed sum ${ }^{107}$ or a fixed percentage of the selling price, ${ }^{108}$

104. 18 Cal. $2 \mathrm{~d}$ at $385-86,115$ P.2d at 499-500. Several other decisions have given special emphasis to California's statutory provisions regulating liquidated damages. See Rice v. Schmid, 18 Cal. 2d 382, 115 P.2d 498 (1941); Wilmington Transp. Co. v. O'Neil, 98 Cal. 1, 32 P. 705 (1893); Anaheim Citrus Fruit Ass'n v. Yeoman, 51 Cal. App. 759, 197 P. 959 (2d Dist. 1921); Ricker v. Rombough, 120 Cal. App. 2d Supp. 912, 261 P.2d 328 (Super. Ct., App. Dep't 1955); Electrical Prods. Corp. v. Williams, 117 Cal. App. 2d Supp. 813, 256 P.2d 403 (Super. Ct., App. Dep't 1955). But other cases see the code sections as a codification of common law rules. See Better Foods Mkts., Inc. v. American Dist. Tel. Co., 40 Cal. 2d 179, 253 P.2d 10 (1953); Weinreich Estate Co. v. A.J. Johnston Co., 28 Cal. App. 144, 151 P. 667 (3d Dist. 1915).

105. This matter is now dealt with by CAL. COMM. CODE $\$ 2708$ (West 1964), which provides that usually the measure of damages is the difference between the market price at the time of breach and the unpaid contract price, plus any incidental damages. However, where this will not provide the seller with the benefit of the original bargain, he is entitled to his net profit plus mcidental damages.

106. See also Hanna Nielsen S.S. Co. v. Hammond S.S. Co., 32 F.2d 31 (9th Cir. 1929) (sale of ships); Porter v. Gibson, 25 Cal. 2d 506, 154 P.2d 703 (1944) (sale of stock).

107. Stark v. Shemada, 187 Cal. 785, 204 P. 214 (1922); Lightner v. Menzel, 35 Cal. 452 (1868).

108. Cf. People v. George, 257 Cal. App. 2d 805, 65 Cal. Rptr. 368 (1st Dist. 1968) (25 percent of contract price to cancel). 
and those attempting other types of alteration of the statutory law, such as giving the buyer the remedy of price without his complying with the normal statutory requirements of tender and delivery. ${ }^{100}$ There have, however, been some exceptions.

The first of these is that, as in lease situations, ${ }^{110}$ the courts will probably enforce clauses hquidating damages for a buyer's breach if goodwill of a business is affected by the breach. The only California case to consider this issue was Bay Shore Motors v. Baker. ${ }^{111}$ During a grey-market period the defendant purchased a car under a written contract that included a provision that he would not sell the car and that the seller could repurchase it upon payment of the full purchase price. If the buyer resold the car in violation of the agreement, the contract specified he would pay the seller $\$ 500$ as liquidated damages. The court was uncertam about whether the clause was valid but reversed to give the buyer a chance to show that no actual damages resulted. While this case does not determine whether sucli a clause is valid, another court permitted hquidation of damages because if the clause were not enforced, causation and certainty requirements would preclude recovering damages even though a resale in violation of the contract could damage the seller's reputation. ${ }^{112}$ Despite the nonenforceability of a liquidation clause, it can still operate in some circumstances to limit hability. This was established in Horrell v. Lakewood Marina, ${ }^{113}$ where the buyer of a boat initially paid $\$ 6,000$ down and later paid an additional $\$ 5,000$ toward the purchase price. After his own breach, buyer brought an action to recover the second $\$ 5,000$ payment, claiming it was her understanding that if she did not go through with the purchase she would not lose more than $\$ 6,000$. The court held the buyer was entitled to recover the $\$ 5,000$.

If a clause liquidating damages does not fit within one of these exceptions, not only is the seller required to prove damages to collect from the buyer, but, absent proof of damages, the buyer is entitled to recover any advance payments he has made minus 20 percent of the contract price or $\$ 500$, whichever is less..$^{114}$

\section{The Commercial Code}

All the cases that have been discussed arose before the enact-

109. Mente \& Co. v. Fresno Compress \& Whse. Co., 113 Cal. App. 325, 298 P. 126 (4th Dist. 1931). See also Denkin v. Sterner, $10 \mathrm{~Pa}$. D. \& C.2d 203 (Ct. C.P., York County 1956).

110. See text accompanying note 92 supra.

111. 90 Cal. App. 2d Supp. 895, 202 P.2d 865 (Super. Ct., App. Dep't 1949).

112. Elizabethtown Lincoln Mercury, Inc. v. Jones, 313 Ky. 321, 231 S.W.2d 42 (1950).

113. 3 Cal. App. 3d 506, 83 Cal. Rptr. 701 (4th Dist. 1970).

114. Cal. CoMm. CODE $\S 2718$ (West 1964). 
ment of the Commercial Code, which seems to encourage the use of liquidation. Section 2718 states:

Damages for breach by either party may be liquidated in the agreement but only at an amount which is reasonable in light of the anticipated or actual harm caused by the breach, the difficulties of proof of loss, and the inconvenience or non-feasibility of otherwise obtaining an adequate remedy. A term fixing unreasonably large liquidated damages is void as a penalty. ${ }^{115}$

Thus, the test is reasonableness of amount according to the code's criteria, and it appears that the clause will be enforced if the amount is reasonable either at the time the contract is made or at the time of trial. This goes farther than prior California cases in two major respects: First, there is no requirement that the amount selected be a reasonable attempt to estimate damages. Second, section 2718 appears to validate clauses that appear to be reasonable in terms of anticipated damages even where the court may believe that the damages are not difficult to ascertain at the time of trial. What impact these changes will have is uncertain, because no California cases have interpreted this section.

\section{Service Contracts ${ }^{116}$}

Few generalizations can be made about service contracts; liquidation clauses im contracts concerning some services are universally enforced, while those im contracts concerning other services are not. It is necessary to consider each type of service contract separately.

\section{Oil Exploration Contracts}

If sales of goods are the prototype transaction where liquidation of damages will not be applied, oil exploration contracts are one of the few areas where it can be confidently predicted that a liquidation clause will be given effect. Without liquidation, because of the difficulty of showing the quantity and quality of oil that would have been extracted had the defendant performed properly, one party who has suffered unprovable damages would not be able to recover anything. ${ }^{117}$ This could tempt the performing party not to perform. As a result, the courts have hberally enforced hquidation clauses in this situation.

115. Id.

116. While some of the cases, such as the water and electric supply cases, could be classified as a type of goods transaction, they are considered service contracts for purposes of this discussion.

117. Ballem, Some Second Thoughts on Damages for Breach of a Drilling Commitment, 48 CAN. B. REv. 698, 698-99 (1970). See Allen v. Narver, 178 Cal. 202, 172 P. 980 (1918); Comment, Damages-Measure of Damages for Breach of Contract to Drill Oil or Gas Well, 13 WASH. \& LEE L. REv. 207 (1956). 
The leading case involving an oil exploration contract is Escondido Oil Co. v. Glaser, ${ }^{118}$ involving an oil development sublease with a clause that provided for $\$ 500$ liquidated damages in the event the developers did not explore as promised. The clause was found to be valid without any discussion of whether the lump sum was a genuine preestimate. The court's only observation was that "the small amount provided in the contract herein involved as liquidated damages is certainly not unconscionable." ${ }^{119}$ In $M c$ Comber $v$. Kellerman, ${ }^{120}$ which involved an oil extraction lease with a sliding scale of payments if the defendant did not drill, the supreme court went one step further: the court lield that the clause was valid as a liquidation provision without any pleading or proof, simply noting that the normal liquidation requirenents "are fully sliown by the lease itself." ${ }^{121}$ Thus, in oil development cases a rule las been crystallized that enforcement is proper without the necessity of going through the proof requirements imposed on liquidation clause enforcement in other types of contracts. ${ }^{122}$

\section{Real Estate Brokerage Contracts}

Real estate brokerage contracts containing liquidation clauses generally have not been troublesome. The few brokerage cases that have been decided suggest that courts will not enforce these clauses because of the ease with whicls a court can deal with the particular actual dainages question. In McInerney v. Mack, ${ }^{123}$ for example, a real estate agent took a $\$ 1,000$ deposit from an owner and was to work out a real estate exchange; the owner defaulted on the exchange and sued to recover his $\$ 1,000$. The court held he could, arguing that, because it is not "difficult or impossible to establish by evidence the reasonable value of lis services,"124 damages could not be liquidated. This conclusion cannot be changed, as has been tried, by claiming that a damages clause represents "time, trouble and expenses."

118. 144 Cal. 494, 77 P. 1040 (1904).

119. Id. at $500,77 \mathrm{P}$. at 1042 .

120. 162 Cal. 749, 124 P. 431 (1912).

121. Id. at $752-53,124 \mathrm{P}$. at 433.

122. Kelly v. McDonald, 98 Cal. App. 121, 276 P. 404 (3d Dist. 1929), seems to cast some doubt on the ease of enforcing liquidation clauses in oil development contracts. There was no allegation of compliance with section 1671 nor any proof of any actual damages, and the court of appeals held the clause invalid for both reasons. Later McCarthy v. Tally, 46 Cal. 2d 577, 586, 297 P.2d 981, 987 (1956), overruled Kelly on the issue of the need for showing actual damages, but the part of Kelly that seems contrary to McComber on the pleading and proof question has never been overruled.

123. 34 Cal. App. 153, 166 P. 867 (1st Dist. 1917). See also Neuer v. King, 276 Cal. App. 2d 461, 478-79, 81 Cal. Rptr. 161, 172-73 (1st Dist. 1969) (dictum).

124. Id. at $157,166 \mathrm{P}$. at 869 .

125. Robert Marsh \& Co. v. Tremper, 210 Cal. 572, 576, 292 P. 950,952 (1930). 
It is possible, however, to use a system that steers away from damages and yet substantially accomplishes the objective of the brokers. Suppose there is no clause hquidating damages and the hister defaults. To recover, the broker must show that he could have found a buyer ready, willing, and able to purchase the property, which sometimes can be a difficult and formidable bar to recovery. The solution is to follow Baumgartner v. Meek, ${ }^{126}$ involving a provision specifying that the broker would get his commission even if the owner sold the property. The owner sold the property and the broker recovered the commission, not because of a breach by the owner in selling, but based upon the provision that sale by the owner would entitle the broker to his commission. In a sense, such a technique is like the alternative performance used so frequently to enforce clauses not passing the tests for valid liquidation of damages; the hister has a choice of either permitting the broker to find a purchaser or paying the broker when he sells it himself. ${ }^{127}$

\section{Legal Services Contracts}

Legal services, like broker's services, are relatively easy to value, and therefore probably cannot be hquidated. While there have been no cases that have directly involved this question, ${ }^{128}$ a few cases have gone into the matter indirectly. Eastman v. Sunset Park Land Co. ${ }^{129}$ involved a note negotiable in form stating that the maker would pay attorneys' fees as set by a court. The maker claimed that such a note was nonnegotiable because of the provision for attorneys' fees. In holding that the note was negotiable, the court stated that it would not be difficult for a court to set fees. The court also noted that attorneys' fees could not be liquidated because the requirements of section 1671 would not be satisfied.

Similarly, in Greenbach Brothers, Inc. v. Burns, ${ }^{130}$ involving a land buyer's atteinpt to recover a deposit, one contention made by the

126. 126 Cal. App. 2d 505, 272 P.2d 552 (3d Dist. 1954). But see Neuer v. King, 276 Cal. App. 2d 461, 478-79, 81 Cal. Rptr. 161, 172-73 (Ist Dist. 1969).

127. Admittedly, such an approach will not work if the owner does not sell the property himself. But there is less likely to be litigation where the owner simply changes his mind. See generally Comment, The Right of a Real Estate Broker to a Commission in California, 8 U.C.L.A.L. Rev. 152 (1961).

128. In a drafting seminar I conducted several years ago I asked students to draft an attorney's contingent fee contract. A number of them included clauses that provided that if the client settled the case without consent of the attorney, the client would pay the attorney a specified and, I might add, exhorbitant hourly rate. When I questioned the professional propriety and enforceability of such a clause, I was informed that they were taken from "reputable" formbooks.

129. 35 Cal. App. 628, 170 P. 642 (2d Dist. 1917).

130. 245 Cal. App. 2d 767, 54 Cal. Rptr. 143 (1st Dist. 1966). 
seller was that liquidation sliould be permitted because he would incur legal expenses that would become valueless if the buyer defaulted in his agreement to purchase the hotel. While there were other grounds for not permitting the seller to retain the deposit, the court noted that the value of legal services is not difficult to ascertain.

\section{Salesman Commission Contracts}

The rule as to genume hquidation clauses in salesman-commission contracts is unclear. The earliest case, Thomas $v$. Anthony, ${ }^{131}$ involved a dealer's breacli of an agency agreement to sell cars that included a recital that the requirements of section 1671 had been inet. In a suit by the dealer to recover a $\$ 1,000$ deposit, the court held a nonsuit for the defendant was improper since the defendant must submit evidence to prove that the contract fell within the requirements of section 1671, rather than relying on the contract recital. The court looked rather suspiciously at the liquidation clause and did not seem happy at the prospect of permitting the defendant to retain the deposit when it appeared that he was not damaged.

A different attitude, however, was displayed in Ramsay v. Rodgers. ${ }^{132}$ In this case, an employer breached a contract providing that if the employee salesman was unjustifiably discharged, he would get damages of one year's salary plus $5 \%$ of certam income made after his termination. While the holding is not clear, it appears the court felt this liquidation clause was valid. Since it would be difficult to compute the amount of actual sales commissions he would have made had he not been wrongfully discharged, this would seem to be a proper case for liquidation of damages. It is certainly difficult to determine at the time the contract is made what sales lie would make, and it is even difficult to determine what sales he would have made at the time of trial. ${ }^{133}$

Whatever the status of genuine liquidation clauses in this situation, it is clear that a liquidation effect can be accomplished by framing a contract in terms of alternate performance. For example, in Powis v. Moore Machinery Co. ${ }^{134}$ the court enforced a clause providing that the salesman's commission would be reduced if he discontinued working for the employer. The court held that the test for liquidation of damages did not have to be met because, when the salesman left the employer, he was not guilty of any breach; the clause simply determined that in case lie left lie would not receive the part of the com-

131. 30 Cal. App. 217, 157 P. 823 (1st Dist. 1916).

132. 60 Cal. App. 781, 214 P. 261 (1st Dist. 1923).

133. See Twentieth Century-Fox Film Corp. v. Woods Amuse. Corp., 304 F. Supp.

23 (N.D. III. 1969) for a rational formula that could be used to liquidate damages.

134. 72 Cal. App. 2d 344, 351-54, 164 P.2d 822, 826-27 (2d Dist. 1945). 
mission based upon future services the salesman was expected to have performed for his customers. The court rejected the contention by the salesman that recitals relating to future services were merely window trimming and a club to keep him in line. This may have been a proper ruling. But, if in fact there was no legitimate justification for the drastic reduction in the salesman's commission when he left the employer, the provision really was a device to keep him in line and should have been classified an unenforceable penalty. However, in these cases courts seem willing to enforce liquidation clauses despite the element of coercion, apparently because they are generally the product of a negotiated contract. ${ }^{135}$

\section{Agricultural Services Contracts}

Usually, cases involving liquidation of damages in the context of an agricultural services transaction concern attempts to liquidate damages for failure to cultivate land or make agricultural miprovements. Seid Pak Sing v. Barker ${ }^{136}$ is typical; it involved an attempt to establish liquidated damages of $\$ 40$ per acre for failure to prepare, dram, clear, plow, and maintain the levees incident to agricultural land leased. The contract clause designated this amount as dannages, but not specifically as liquidated damages. The court held the clause partially invalid under section 1670 on the ground that it was not too difficult to ascertain the damages where existing crops were lost; the court did, however, uphold the clause as to loss of prospective crops because damage for this loss was too difficult to ascertain. The same result has been reached in other cases involving the failure to maintain or improve agricultural land. ${ }^{137}$ Even in cases where the breach was the failure to grow crops, the courts have generally believed the damages to be easily ascertainable and have therefore refused to enforce liquidation clauses. ${ }^{138}$

\section{Utility Service Contracts}

Two different situations can arise relating to breach of a utility service contract. The first is the utility's failure to supply the promised electricity or water. Here the courts have consistently held that, be-

135. See also Buskuhl v. Family Life Ins. Co., $271 \mathrm{Cal}$. App. 2d 514, $76 \mathrm{Cal}$. Rptr. 602 (2d Dist. 1969); Bach v. Curry, 258 Cal. App. 2d 676, 66 Cal. Rptr. 220 (1st Dist. 1968).

136. 197 Cal. 321,240 P. 765 (1925).

137. See Ebbert v. Mercantile Trust Co., 213 Cal. 496, 2 P.2d 776 (1931); City of Vernon v. Sonthern Cal. Edison Co., 191 Cal. App. 2d 378, 12 Cal. Rptr. 701 (2d Dist. 1961) (repossession of plant without compensation).

138. See Meer v. Cerati, 53 Cal. App. 497, 200 P. 501 (3d Dist. 1921) (underliquidation of damages). 
cause the amount of actual damages would be difficult to establish, either at the time the contract was made or at the time of trial, liquidation clauses are enforceable. For example, in Pogue v. Kaweah Power \& Water Co. ${ }^{139}$ a farmer conveyed rights of way, water rights, and land in excliange for the utility's promise to supply water to the farmer. The contract specified that the utility would reconvey the water rights and riglits of way to the farmer in the event of breach. The court considered the provision a liquidation clause and lield that it is valid because damages for failure to supply water are "uncertain and not susceptible of computation."140

The second situation involves a contract between a user and the utility for a specified minimum amount of utility service that makes the user liable for an amount of money regardless of actual use. In Marin Water \& Power Co. v. Town of Sausalito, ${ }^{141}$ California's leading case, the court held that a clause of this type was not a liquidation of damages clause, but an alternative performance provision. Clearly it was justified in this case, since the water company liad expended a substantial amount of money in building a line to the town, and it is likely the minimum amount reflected the sum necessary to recoup this investment. ${ }^{142}$

\section{News Service Contracts}

The validity of a liquidation clause in a news service contract lias been considered by only one California case, Associated Press v. Emmett, ${ }^{143}$ whicl involved a membership contract in Associated Press with a provision for a two-year notice of withdrawal. The defendant newspaper gave a short notice to terminate and plaintiff sued for damages. The court upleld the two-year notice provision, which, in effect, required the subscriber to pay for a two-year period whether lie wanted to use the services or not, on the ground that supplying news was not like supplyimg a product like flour. Sucli services cannot be valued since they are not a market product. Therefore, the court only required that the liquidated "damages ... [not be] disproportionate to the damage they might suffer from breacli."144 Today a court might take a different approach in light of the increasing tendency to

139. 138 Cal. 664,72 P. 144 (1903).

140. Id. at 668,72 P. at 145 . But see Hansen v. Vallejo Elec. Light \& Power Co., 182 Cal. 492, 188 P. 999 (1920).

141. 168 Cal. 587, 143 P. 767 (1914).

142. See also City of Memphis v. Ford Motor Co., 304 F.2d 845 (6th Cir. 1962), discussed in MacNeil, An Exercise in Contract Damages, 4 B.C. IND. \& CoM. L. REv. 331, 335-37 (1963).

143. 45 F. Supp. 907 (S.D. Cal. 1942).

144. Id. at 920 . 
police contracts with antitrust overtones, but because the news service would lave great difficulty establishing actual damages when a subscriber cancels, the court's decision was proper.

\section{Alarm Service Contracts}

The alarm service cases, Atkinson v. Pacific Fire Extinguisher Co. ${ }^{145}$ and Better Foods Markets, Inc. v. American District Telegraph Co., ${ }^{146}$ created a great stir when they were decided in 1953. Atkinson involved a contract to supply a fire extinguishing system with a $\$ 25$ liquidation of damages clause; Better Foods involved a contract for a burglar alarm system with a $\$ 50$ liquidation clause. Because Better Foods contains the most significant and most cited argument, the discussion focuses upon that case.

By contract the burglar alarm company imstalled and agreed to maintain an alarm system for the plaintiff supermarket. A clause in the contract stated that the burglar alarm company was not to be considered an insurer and that, because of the difficulty of fixing actual damages, the parties agreed to $\$ 50$ as liquidated damages. The burglar alarm company failed to promptly notify the police of a robbery, and the robbers escaped with approximately $\$ 36,000$. Noting the necessity that the parties know their exposure to liability in this situation, the supreme court upheld the clause. The plamtiff had argued that there was no difficulty in establishing the actual damage because the time for determining the "question of the impracticability and difficulty in fixing the damages is after the loss has occurred."147 The court rejected this, holding that the important time for determining this question was at the time the contract was made. ${ }^{148}$

This was a proper decision. The burglar alarm system may have involved use of new scientific techniques that, along with human error, could expose the burglar alarm company to high risks. That they thought they liad transferred this risk to the user is sliown by the clause, the language that the company was not an insurer, and the $\$ 15$ a month charge. If they could not contract away this risk, they would have to insure; and since it is likely that the user would also insure, this would probably result in overinsurance. Such a clause sliould be enforced in a high-risk, low-compensation service when enforcement is what the parties expected. ${ }^{149}$

145. 40 Cal. 2d 192, 253 P.2d 18 (1953).

146. 40 Cal. 2d 179, 253 P.2d 10 (1953).

147. Id. at $185,253 \mathrm{P} .2 \mathrm{~d}$ at 14 .

148. Id.

149. See also Zurich Ins. Co. v. King Indus., Inc., 255 Cal. App. 2d 919, 63 Cal. Rptr. 585 (2d Dist. 1967). 


\section{Educational Services Contracts}

Only one California case, Stewart v. Claudius, ${ }^{150}$ has concerned the general problem of student attempts to recover tuition paid when they either do not enroll or leave prior to the end of the instruction period. In Stewart, a student at a military academy was expelled for being absent without leave. The school attempted to collect the unpaid balance of the tuition under a clause stating that, if the student were dismissed, the unpaid portion of tuition would become payable as liquidated damages. The appellate court held that there was not a breach and, therefore, that the clause was not one for liquidation of damages; it was simply an alternative performance clause under which the parent of the student would pay the entire tuition without regard for any dismissal of the student.

Arguments can be made for making tuition nonrefundable. Schools plan their programs upon an estimated number of attendimg students; making refunds to students who do not enroll after being accepted or who leave in midterm could hamper fiscal planning. Even if one adopts an unjust enrichment philosophy, the defaulting student's recovery must be dimmished by actual damages that result from his breach. One accepted measure of recovery is the proimised performance, payment of tuition, less the expenses he saved the school by not enrolling or leaving early. Application of this measure would usually preclude refunds, because rarely does the school save anything by the student's breach. Only if the breaching student's absence enabled the school to admit another student could it be said that, apart from minor administrative expenses, the school was not damaged by the breach.

Yet, it seems unfair that the student should lose his tuition when lie is unable to enroll or continue in school. Whether a university should be permitted to retain any of the tuition is not a matter that should be deternined by general contract law. A statutory enactment, perhaps one providing for a sliding scale forfeiture, could better fit this specialized problem.

\section{E. Construction Contracts}

Careful lawyering at the drafting, pleading, and proof stages will make a liquidation clause for delay enforceable despite, on occasion, the availability of a recognized measure for actual damages and the lack of a genuine attempt to estimate damages. The enforceability of clauses liquidating damages for other types of breaches in construction contracts is less clear.

150. 19 Cal. App. 2d 349, 65 P.2d 933 (1st Dist. 1937). 


\section{Owner Breaches}

Liquidation in construction contracts typically concerns breaches by the contractor, because the owner's obligations are fewer in number and principally consist of making payments. There are, however, obligations of the owner that could be the subject of liquidation of damages clauses. For example, the owner might breach by an unexcused delay in furnishing the site to the contractor, by supplying imcorrect soil data or by delaying the contractor's performance while on the site. But in construction contracts it is the owner who generally has the superior bargaining position, and he rarely feels the need to underliquidate damages for delay he causes. He uses a more direct approach to relieve himself of this risk, such as a clause permitting the owner to interrupt the contractor's work when in the owner's judgment it is necessary to do so $^{151}$ or a clause limiting the contractor to an extension of time without any right to recover delay damages. The majority of courts enforce these "no damage" clauses, ${ }^{152}$ and a fortiori such courts slould allow an owner to employ a liquidation clause to set the amount of damages.

But delay caused by the owner or misrepresentation of soil data generally increase the cost of doing the work to the contractor, and this is a type of damages that courts are generally able to handle. Since these costs are relatively easy to prove at the time of trial-apart from a possible dispute over causation or foreseeability-it is unlikely that a court would enforce a liquidated damages clause for these breaches. On the other hand, some types of owner breach, such as unjustifiable removal of the contractor from the project site, might create a situation where standardized measures of recovery are not sufficient for the contractor. For example, one standardized measure of recovery for the contractor is the cost of his part performance plus his profits; often contractors attempt to show profit margims by generally accepted profit margins in the construction industry, but a contractor might wish to agree in advance on an accepted profit margin. Such an agreement should be given effect.

151. But see CaL. Civ. CoDe $\$ 1511(1)$ (West 1970); Sweet, Extensions of Time and Conditions of Notice: California's Needless Restrictions of Contractual Freedom, 51 CALIF. L. Rev. 720 (1963).

152. Sweet, Owner-Architect-Contractor: Another Eternal Triangle, 47 CALIF. L. Rzv. 645, 681 (1959). In Hawley v. Orange County Flood Control Dist., 211 Cal. App. 2d 708, 27 Cal. Rptr. 478 (4th Dist. 1963), the court considered a "no damage" clause as creating a forfeiture aud therefore held that it must be strictly construed, especially where the contract was prepared by the party seeking protection from his delay. The court finally concluded the clause did not apply to unreasonable delay caused by matters not within the contemplation of the parties. 


\section{Contractor Breaches}

The principal contractor breaches are not entering into the contract when awarded, not constructing the project in accordance with the plans and specifications, unexcused delay in completing the project, and failing to pay subcontractors and suppliers. Of these, the principal areas for liquidation have been failure to enter into the contract when awarded and unexcused delay in completion, but one case has also arisen involving a clause liquidating damages for defective performance.

a. Defective performance. A 1909 case, Sherman v. Gray, ${ }^{153}$ establislied that damages for a contractor's defective performance cannot be liquidated. The Sherman contract had a blunderbuss clause, one lump suin that applied to any breach by either party; it was clearly a penalty, and the court so held. However, the court did not rest its decision exclusively on the penalty aspect; it argued that, because the cost to correct any deficient work by the contractor would be a "simple, [sic] matter to ascertam,"154 the case fits within the general rule against enforcing liquidated damages clauses where the damages are relatively easy to calculate at the trial. Since Sherman, no cases have ever arisen attempting to liquidate damages for a contractor's defective performance; the bar seems to have accepted that liquidation is inappropriate in these circumstances.

b. Failure to enter into a contract when awarded. At the outset it must be determined whether the parties properly attempted to liquidate damages. In the typical case each bidder must put up a specified percentage of his bid either by a certified check or bid bond. If this is all that is specified, it leaves open the question whether this amount constitutes an attempt to hquidate damages. Certainly if the contract purports to give the owner the option of treating the deposit as liquidated damages or suing for actual damages, ${ }^{155}$ the amount should not be considered one of liquidated damages; a genuine liquidated damages clause must control the issue of the amount of damages. To be an unequivocal liquidation clause, the invitation to bidders should state that the amount deposited by the bidder is nonrefundable in the event the successful bidder has no legally sufficient reason for not entering into the contract, and for further safety it should at least recite the statutory language of section 1671 and that the amount is a reasonable endeavor to preestimate damages.

If a properly written clause establishes that the amount deposited

153. 11 Cal. App. 348, 104 P. 1004 (1st Dist. 1909).

154. Id. at $352,104 \mathrm{P}$. at 1005.

155. Sometimes the option is given by law. See Kemper Constr. Co. v. City of Los Angeles, 37 Cal. 2d 696, 235 P.2d 7 (1951). 
is an attempt to liquidate damages, the courts liave disagreed as to whether it will be enforced. ${ }^{156}$ However, in the most recent case on this issue, Petrovich v. City of Arcadia, ${ }^{157}$ the California supreme court authoritatively settled the issue for this state. The action was brouglit by a successful bidder against the city of Arcadia to cancel his bid to construct sanitary improvements on the grounds of mistake: he had inadvertently omitted a large cost item. The city cross-complained, joined the surety, and asked for forfeiture of the bid bond for $\$ 37,500$ plaintiff had deposited. The next low bid was some $\$ 69$,000 higher than the plaintiff's bid. The supreme court's narrow holding in the case was only that, because neither the invitation to the bidders nor the bond explicitly provided for forfeiture, the city had to sue for actual damages. ${ }^{158}$

Nevertheless, the court went on to discuss what would have been the result had the invitation or bond provided for forfeiture. The court concluded that, despite the contrary practice of several other jurisdictions, ${ }^{150}$ in California compliance witl section 1671 was a question of fact that must be alleged ${ }^{160}$ and proved. Therefore in this case, even if the bid had been properly drafted, the city would fail, because there had been no specific showing of the difficulty of ascertaining actual damages or good-faith preestimation. Although this point is dictum, it appears to establish that sections 1670 and 1671 will be strictly applied in this area. ${ }^{161}$

This requirement of strict comphance may mean it will be impossible to hquidate damages for a contractor's failure to enter into the contract. Actual daniages are usually not too difficult to determine. If the bidder does not enter into a contract awarded to him, there are at least three possibilities open to the awarding authority: it may award the contract to the next low bidder, it may readvertise and award the contract to the lowest responsible bidder, or it may decide to abandon the project. Unless the project is abandoned, major daniages are generally easy to determine; they consist of the difference between the de-

156. Compare City of Los Angeles v. Shafer, 53 Cal. App. 458, 200 P. 384 (2d Dist. 1921) (enforcement refused) with Palo \& Dodini v. City of Oakland, 79 Cal. App. 2d 739, 180 P.2d 764 (1st Dist. 1947) and Town of Mill Valley v. Massachusetts Bonding \& Ins. Co., 68 Cal. App. 372, 229 P. 891 (1st Dist. 1924) (enforcement granted).

157. 36 Cal. $2 d 78,222$ P.2d 231 (1950).

158. Id. at $84-85,222$ P.2d at 236 .

159. Id. at 83-84; 222 P.2d at 235-36; see 5 CoRBIN $\$ 1074$.

160. But in Bilardi Constr., Inc. v. Spencer, 6 Cal. App. 3d 771, 86 Cal. Rptr. 406 (1st Dist. 1970), the court held a clause could be enforced despite the failure to plead compliance with section 1671 because the issue of validity was raised by the pretrial order.

161. See also CaL. ANN. Gov'T CODE $\$ \$ 37933,37935$ (West 1968) (city can retain security deposit, but it must return any portion that exceeds the difference between the bid origimally accepted and the next low bid). 
faulting bidder's bid and the bid that is ultimately accepted, and in cases where readvertising is necessary, the administrative expense of conducting another competitive bid. Delay in completion of the project, usually caused by readvertising or abandonment of the project, also usually causes major losses to the public, but they are unprovable. In addition there will be minor damages, such as the administrative expense in having to deal with the bidder who is awarded the contract but refuses to enter into it.

The incidental losses, such as administrative expense, and the unprovable losses, such as inconvenience to the public, appear to have been ruled out as the bases for liquidation by the dictum in the Petrovich case. Sucli losses seem disproportionate to the amount deposited and it would not seem fair to make this the basis for liquidation. The delay caused by readvertising and the inconvenience to the public often caused by abandonment would seem sufficient to justify liquidation, but the Petrovich case was an abandonment case, so it appears that that issue has been resolved agamst liquidation. ${ }^{\mathbf{1 0 2}}$

c. Unexcused delay. Construction contracts frequently liquidate damages for unexcused delay by the contractor. Typically, delay is liquidated by assessing a specified amount or a percentage of the bid price ${ }^{103}$ for each day of unexcused delay, although occasionally a lump sum liquidation is employed. ${ }^{\mathbf{1 0 4}}$ While a few cases have refused to enforce clauses setting damages for unexcused delay, ${ }^{105}$ it is well settled in California that suclı clauses are enforceable. ${ }^{108}$

162. If the awarding authority is concerned about losing minor damages, it could protect itself at the drafting stage by splitting the deposit into two parts, one for major and one for minor damages. For example, if the deposit would normally be $10 \%$, the bidder would be asked to deposit an amount of $9 \%$ of his bid as a security deposit and $1 \%$ as liquidation for overhead and the intangible damages that could bo caused if the successful bidder does not enter into the contract. In such a case the awarding authority would be able to sue for actual damages, with the $9 \%$ as security, and keep the $1 \%$ to cover administrative expenses. 1952).

163. E.g., Broderick Wood Prods. Co. v. United States, 195 F.2d 433 (10th Cir.

164. Leshe v. Brown Bros., Inc., 208 Cal. 606, 283 P. 936 (1929); Nash v. Hermosilla, 9 Cal. 584 (1858).

165. Patent Brick Co. v. Moore, 75 Cal. 205, 16 P. 890 (1888) (failure to prove coinpliance with section 1671 in judgnent roll case); Muldoon v. Lynch, 66 Cal. 536, 6 P. 417 (1885) (payment described in the clause as a forfeiture; long delay that did not appear to bo the fault of the builder); Nash v. Hermosilla, 9 Cal. 584 (1858) (lump sum clause).

166. See Peter Kiewit Son's Co. v. Pasadena City Junior College Dist., 59 Cal. 2d 241, 379 P.2d 18, 28 Cal. Rptr. 714 (1963), criticized in Sweet, supra note 151 passim; Silva \& Hill Constr. Co. v. Enıployers Mut. Liability Ins. Co., 19 Cal. App. 3d 914, 920, 97 Cal. Rptr. 498, 501 (2d Dist. 1971); Nomellini Constr. Co. v. State ex rel. Dep't of Water Resources, 19 Cal. App. 3d 240, 246, 96 Cal. Rptr. 682, 686 (3d Dist. 1971); London Guar. \& Acc. Co. v. Las Lomitas School Dist., 191 Cal. App. 2d 423, 12 Cal. Rptr. 598 (1st Dist. 1961); Hanlon Drydock \& Shipbuilding Co. v. 
Most of the cases enforcing such clauses have been state public contracts. In such contracts the courts have been influenced by Government Code section $14376,{ }^{167}$ which provides that eacli state contract shall contain such a clause and that the clause determines the amount forfeited and paid to the state in the event of unexcused delay. In Silva \& Hill Construction Co. v. Employers Mutual Liability Insurance Co., ${ }^{168}$ the court of appeals held that, while sections 1670 and 1671 apply generally to contracts between public agencies and private individuals, section 14376 of the Government Code is

a legislative determination that late charges imposed on a construction company by a state contract fall within the provisions of section 1671 of the Civil Code and as such are valid hquidated damages. ${ }^{160}$

Recognizing that it would be difficult if not impossible to prove actual damages when a public project is not completed on time, the court argned that section 14376 is an attempt to overcome this so that the state will be at least partially reimbursed for additional cost, lost public benefits, and overliead expenses and that the contractor will be encouraged to work toward timely completion of the work. ${ }^{170}$

Arguably, liquidation is less appropriate in commercial construction or public projects that have an establishable commercial use value. While a few cases in other jurisdictions have not enforced liquidation clauses in contracts involving the construction of residences, ${ }^{171}$ California's law seems established by Hanlon Drydock \& Shipbuilding Co. v. G.W. McNear, Inc., ${ }^{172}$ which uplield a per diem clause hquidating

G.W. McNear, Inc., 70 Cal. App. 204, 210, 232 P. 1002, 1004 (1st Dist. 1924) (ship repair delay).

167. CaL. ANn. Gov'r Code $\$ 14376$ (West 1968).

168. 19 Cal. App. 3d 914, 97 Cal. Rptr. 682 (2d Dist. 1971).

169. Id. at 920,97 Cal. Rptr. at 501.

170. Id. at 918, 97 Cal. Rptr. at 500. Similarly, in Bethlehem Steel Corp. v. City of Chicago, 350 F.2d 649, 650 (7th Cir. 1965), the court upheld a liquidated damages clause for delay that contained this recital:

The work under this contract covers a very important section of the South Route Superhighway, and any delay in the completion of this work will materially delay the completion of and opening of the South Route Superhighway thereby causing great inconvenience to the public, added cost of engineering and supervision, maintenance of detours, and other tangible and intangible losses.

171. See, e.g., Cohn \& Conway v. Birchard, 124 Iowa 394, 100 N.W. 48 (1904); Seeman v. Biemann, 108 Wis. 365, 84 N.W. 490 (1900). However, some cases have enforced liquidation clauses that have substantially exceeded rental value when damages other than loss of use were reasonably foreseeable at the time the contract was inade. See Curtis v. Van Bergh, 161 N.Y. 47, 55 N.E. 398 (1899); cf. Brown Iron Co. v. Norwood, 69 S.W. 253 (Tex. Civ. App. 1902). See also 5 Corsin $\$ 1072$.

172. 70 Cal. App. 204, 232 P. 1002 (1st Dist. 1924). But see General Ins. I Co. v. Commerce Hyatt House, 5 Cal. App. 3d 460, 472, 85 Cal. Rptr. 317, 325 (2d Dist. 1970) (liquidated damages are a penalty not favored in equity). 
damages for delay in ship repair. This is reasonable. Even rental or use value of a residence or office building, while a well-accepted measure of recovery, can be difficult to establish. Also, delayed completion of a residence can involve damages in addition to loss of use. ${ }^{173}$ Moreover, most contracts of this type are negotiated. Therefore, if the amount selected is within the range of likely damages, whether provable or not, such clauses should be enforced. While there is no available data on how liquidation amounts in these contracts are determined, ${ }^{174}$ there is some instructive material by Elliott, a bridge engineer of the California Division of Highways, who states:

The sole purpose of a completion assessment is to assure that the contract work will be done within the time specified, ... to threaten the Contractor with sufficient monetary loss so that he will find it advantageous to apply sufficient men and equipment to the work to get it done on time. Whereas moderate liquidated damages such as $\$ 100$ per day may well be used to insure the completion of a normal project having no special urgency, higher amounts are used to force faster work on jobs which inust be finished in less than a normal construction time. High assessments may be used to emphasize the need for haste and should be of sufficient size to make it economically desirable that the contractor expedite his work by use of multiple shifts or additional equipment. ${ }^{175}$

Although most such construction contract liquidation clauses would not pass muster as genuine attempts to estimate damages as required by section 1671, they are usually enforced. There are a number of reasons for this. First, while the liquidation amounts may not actually be bargained, the contractor can take this into account when he makes his bid. ${ }^{176}$ Second, inost construction contractors are not so unsophisticated as to merit special protection by the courts. ${ }^{177}$ Third, courts enforce these clauses as a means of saving themselves from having to decide difficult fact questions relating to damages. Finally, these clauses are enforced because delays do cause losses, but the actual loss is often not provable under traditional damage rules, which require certamty, proof of causation, and foreseeability.

Apart from problems of enforceability, clauses liquidating damages

173. See note 171 supra.

174. The process was recently claimed to be constitutionally defective. See Brief for Contractor's Ass'n as Amicus Curiae, Silva \& Hill Constr. Co. v. Employer's Mut. Liab. Ins. Co., 19 Cal. App. 3d 682, 97 Cal. Rptr. 498 (2d Dist. 1971).

175. H. Jones, A. FARNSWORTH \& W. Young, CASEs aNd Materials on Contracts 700 (1965).

176. Id. at 714 .

177. See Bethlehem Steel Corp. v. City of Chicago, 350 F.2d 649, 651 (7th Cir. 1965); cf. Southwest Eng'r Co. v. United States, 341 F.2d 998 (8th Cir. 1965). 
for contractor delay have caused difficulty because of a number of interpretation questions that have arisen. First, sometimes the delay is caused by the contractor and by the owner or someone for whose acts the owner is responsible. Because a court will not apportion responsibility for the total delay between those causes for which the contractor is responsible and those for which he is not, ${ }^{178}$ the liquidated damages clause can be applied only if the parties provide for apportionment by contract. ${ }^{179}$

The second interpretation problem courts frequently face is determining when a project is completed for liquidation purposes. The general answer is that actual, not substantial, completion is required. ${ }^{180}$ However, courts will be hesitant to apply this rule where the stipulated damages are high and the project is available for use. ${ }^{181}$

A final interpretation problein that has troubled the courts is what happens when the contractor abandons the project and the liquidated damages clause is silent on abandonment. When this occurs, the owner typically hires another contractor to complete the project. In such a case, there can be two elements of damage. First, the total cost of the project may be imcreased because of the necessity of hiring another contractor and incurring a greater expense than originally specified in the contract. Generally, the owner is entitled to this additional expense as part of actual damages. Second, the contract will probably be completed by the substitute contractor beyond the contract date. Since two elements of damages are involved in these abandonment and completion-by-a-substitute-contractor cases, it would seem that the owner should be able to recover both his added costs in securing a substitute contractor and liquidation based upon when the project is actually completed, but the two California cases to consider this question have allowed only actual damages. ${ }^{182}$ This may be because when both of the items are totaled the damages can be quite formidable.

178. General Ins. Co. v. Commerce Hyatt House, 5 Cal. App. 3d 460, 85 Cal. Rptr. 317 (2d Dist. 1970); Aetna Cas. \& Sur. Co. v. Board of Trustees, 223 Cal. App. 2d 337, 35 Cal. Rptr. 765 (1st Dist. 1963); Gogo v. Los Angeles County Flood Control Dist., 45 Cal. App. 2d 334, 114 P.2d 65 (2d Dist. 1941). See Pettit \& Gleason, Liquidated Damage in Government Contracts, 25 Sw. L.J. 264, 273 (1971).

179. Nomellini Constr. Co. v. State ex rel. Dep't of Water Resources, 19 Cal. App. 3d 240, 96 Cal. Rptr. 682 (3d Dist. 1971); Sweet, supra note 152, at 722.

180. See London Guar. \& Acc. Co. v. Las Lomitas School Dist., 191 Cal. App. $2 d$ 423, 12 Cal. Rptr. 598 (1st Dist. 1961).

181. See Hungerford Constr. Co. v. Florida Citrus Exposition, Inc., 410 F.2d 1229 (5th Cir. 1969).

182. Sinnott v. Schumacher, 45 Cal. App. 46, 187 P. 105 (1st Dist. 1919); Bacigalupi v. Phoenix Bldg. \& Constr. Co., 14 Cal. App. 632, 112 P. 892 (1st Dist. 1910). See also Six Companies v. Jomt Highway Dist. No. 13, 311 U.S. 180 (1940). 


\section{F. Covenants Not to Compete}

Covenants not to compete are one type of breach where liquidation clauses are almost always enforced. ${ }^{183}$ This is true whether, as is usually the case, the stipulated amount is a lump sum or a sliding scale based upon the time of breach and other variables. ${ }^{184}$ Even stipulated forfeitures of a lump sum equal to the total contract price lave repeatedly been enforced in California. ${ }^{185}$ While it might be argued that these lump sum amounts are selected as an averaging of potential damages that might result from the various differences in time and geographical location of competition, it is more likely that they are chosen simply by a bargaining process. In any case, contrary to the usual rule, ${ }^{186}$ courts have enforced these hiquidated damages clauses without pleading or proving compliance with section $1671 . .^{187}$

The reasons courts have allowed so much party autonomy in this particular situation are twofold. First, courts have recognized that these contracts are generally negotiated between parties of relatively equal bargaining strength and therefore have refused to relieve a complaining party "from the hardships of an agreement into which he has willingly and knowingly entered."188 Second, and more important, courts lave thought actual damages in this field absolutely incapable of determination, ${ }^{189}$ so they have enforced liquidation clauses to avoid making it possible for a breaching party to violate the contract with impunity.

Despite the enforceability of genuine liquidation clauses in covenants not to compete, there seems to be a tendency in some recent cases to use alternate performance instead. For example, the partnership agreement in Farthing $v$. San Mateo Clinic ${ }^{190}$ provided that, if the partner should leave, he would receive his share of the accounts receivable at the rate of $\$ 400$ per month, but if he should relocate in the

183. 5 CORBIN $\$ 1071 ;$ MCCORMICK $\$ 156$, at 621 .

184. McCormick states that a graduated amount would increase the chances of enforcement. MCCoRMick $\& 156$, at 621 .

185. See, e.g., Potter v. Ahrens, 110 Cal. 674, 43 P. 388 (1896); California Steam Navigation Co. v. Wright, 6 Cal. 258 (1856). But see Morris v. Harris, 127 Cal. App. 2d 476, 274 P.2d 22 (1st Dist. 1954), holding a clause invalid since the negative covenant liquidated was a violation of CAL. ANN. Bus. \& Prop. CODE $\$ 16600$ (West 1968), which makes trade restraints invahd unless the restraint falls within a statutory exception.

186. See note 292 infra.

187. See Akers v. Rappe, 30 Cal. App. 290, 158 P. 129 (1st Dist. 1916); Shafer v. Sloan, 3 Cal. App. 335, 85 P. 162 (2d Dist. 1906).

188. See Streeter v. Rush, 25 Cal. 67, 72 (1864).

189. Potter v. Ahrens, 110 Cal. 674, 681, 43 P. 388, 389 (1896); California Steam Navigation Co. v. Wright, 6 Cal. 258, 263 (1856); Shafer v. Sloan, 3 Cal. App. 335, 337-38, 85 P. 162, 163-64 (2d Dist. 1906).

190. 143 Cal. App. 2d 385, 299 P.2d 917 (1st Dist. 1956). 
same area, he would forfeit his share of accounts receivable since he would be getting a share of the clientele. The trial court finding that this was valid as an alternative performance or a liquidation of damages provision was affirmed by the court of appeals. Classifying this type of clause as possibly one for alternative performance would deny the clinic a right to enjoin the withdrawing partner from competing. However, losing the right to enjoin violation may not matter, because the alternative performance in such a case can be a heavy club over the head of a partner. Often the contract will not provide simply for profits ${ }^{191}$ he would have made if he competed but the full amount of fees collected. ${ }^{102}$ Since the offending partner would have to expend money to produce those fees, compelling him to turn over his gross fees would indeed be a powerful coercive measure.

\section{G. Associational Transactions}

Individuals with a common purpose often agree to organize groups and attempt to accomplish their objective by the use of solidarity and group pressures. Violation of such organizational agreements often produces no damages that can be calculated in court, but the prestige of the group can be affected by deviations on the part of members. It is therefore common to attempt to liquidate damages.

The associational arrangement that has caused the most litigation in California relates to marketing cooperatives. ${ }^{193}$ The leading case is Anaheim Citrus Fruit Association v. Yeoman, ${ }^{194}$ where a marketing cooperative sought to enforce a liquidation clause of 50 cents per box against a member who had not marketed his product in accordance with association rules. The court upheld the provision, arguing that it satisfied section 1671 because actual damages would involve some unascertainable effeet upon the "prestige and standing of the Association as a marketing concern." 195

Other market cooperative cases suggest that there may be some

191. In Mellor v. Budget Advisors, Inc., 415 F.2d 1216 (7th Cir. 1969), the court seemed appreheusive about enforcing a clause under which the breaching party would pay the profits he earned from competing. Instead of citing the many cases enforcing liquidation in covenant-not-to-compete arrangements, the court cited Uniform Commercial Code section 2-718, which says clauses must be reasonable, and held this was not a proper case for summary judgenent.

192. See Swenson v. File, 3 Cal. 3d 389, 475 P.2d 852, 90 Cal. Rptr. 580 (1970).

193. Statutes have validated hquidation clauses in certain marketing cooperative agreements. See, e.g., CAL. ANN. AGRIc. Code $\$ 54264$ (West 1968) (nonprofit associations).

194. 51 Cal. App. 759, 197 P. 959 (2d Dist. 1921).

195. Id. at 763, 197 P. at 961 . See also Colına Vegetable Ass'n v. Bonetti, 91 Cal. App. 103, 267 P. 172 (1st Dist. 1928) (lump sum for any violation upheld); Poultry Producers, Inc. v. Murphy, 64 Cal. App. 450, 221 P. 962 (1st Dist. 1923) (lump sum for failure to dehiver eggs upheld). 
limitations on the enforceability of liquidation clauses in these contracts. Nakagawa v. Okamoto, ${ }^{196}$ a case decided by the supreme court prior to Anaheim, involved an agreement between members of the Japanese Farmers Association under which all members would take their business to a new market. The members signed notes for $\$ 500$ "in order to show their good faith." The court concluded that the purpose of these provisions "was apparently to furnish a club to be used to prevent any person signing the agreement from returning to the Third Street Market, by making him liable to a penalty or fine of five hundred dollars if he so did, absolutely irrespective of any question of damage," ${ }^{107}$ and therefore refused to enforce the notes. It is uncertain why the court decided Nakagawa as it did. One probable reason is that the Nakagawa amount was a lump sum unrelated to the extent of the breach; in Anaheim the amount was a certain sum per box. Also, one suspects that the court may have been somewhat sympathetic to the Japanese farmers, many of whom may not have entered into such a group voluntarily.

Another limitation on liquidation in market cooperative contracts is shown by the supreme court decision in Olson v. Biola Corp. Raisin Growers Association, ${ }^{198}$ which refused to enforce a clause liquidating damages for defects in quality of raisins supplied by an association member to the association. In this situation the prestige of the association is not affected, so the courts treat the situation like any other goods transaction and follow the general rule that liquidation of damages in goods transactions will not be enforced. ${ }^{199}$

The problem of liquidation clauses in association contracts has also arisen in connection with labor relations. For example, in Dyer Brothers Golden West Iron Works $v$. Central Iron Works, ${ }^{200}$ there was an agreement between employers who were dealing with the same unions. Each member gave a promissory note to the association, in an anount based upon the member's business volume, that would be forfeited if he dealt with the unions individually rather than through the association. One member breached, and the association brought an action on the note. Without deciding the ultimate issue, the supreme court held that the validity of the clause was a fact question and could not be determined by a demurrer. Also, the court noted that the amount that would be forfeited bore a rational relationship to the

196. 164 Cal. 718, 130 P. 707 (1913).

197. Id. at $723-24,130 \mathrm{P}$. at 709 .

198. 33 Cal. $2 \mathrm{~d} 664,204$ P.2d 10 (1949).

199. See text accompanying notes $94-215$ supra. While one would think a breach of quality would affect association prestige, the case seems to have been one where no actual damage occurred.

200. 182 Cal. 588, 189 P. 445 (1920). 
actual damage and that at least the facts alleged did not indicate that this was solely a club. Because of the uncertain damage the association would suffer if a single mernber breached, the clause probably should be enforced.

A recent case, California State Council of Carpenters v. Superior Court, ${ }^{201}$ involved a different sort of labor relations problem. Here a collective bargaining agreement provided that employers would not pay based upon piece work and specified that the employer would forfeit $\$ 250$ per employee per week as long as he failed to pay wages in accordance with the agreement. The clause stated:

The parties recognize and acknowledge that proper payment of wages is essential to the maimtenance of the Agreement, the health and safety of workmen, and fairness to all employees in the industry, and that it would be extremely difficult if not impracticable to fix the actual expense and damages to the workmen and the industry from any failure to pay wages in accordance with the provisions of this Agreement. Therefore, the amount of damage resulting from such failure shall be presumed to be the sum of Two Hundred and Fifty Dollars $(\$ 250.00)$ for each infraction for each employee, for each week in which the infraction occurs. . . . ${ }^{202}$

The court referred the validity of this provision to the arbitrator because it involved a question of fact; it could not be stated as a matter of law whether the requirements of section 1671 were met. Again, because one can visualize damage of an unascertainable amount to the union and workers if employers deviate from the collective bargaining agreement, it probably should be enforced.

The result in cases like Dyer and California State Council of Carpenters cannot, however, be predicted solely on the basis of hquidation law; undoubtedly, they depend to some degree on the court's view of the desirability of the objectives sought by the association. In a period when employers dominate unions, a court might not be so solicitous toward employer association provisions that place heavy controls over employer association mernbers. Also, the results in these cases may depend upon the court's attitude toward free trade and economic concentration of power. Certainly if, as in Carl N. Swenson Co. v. E.C. Braun Co., ${ }^{203}$ the association agreement violates an antitrust act, it will not be enforced. The type of harm involved may justify enforcement of a liquidation clause, but antitrust policies are more

201. 11 Cal. App. 3d 144, 89 Cal. Rptr. 625 (4th Dist. 1970).

202. Id. at $150,89 \mathrm{Cal}$. Rptr. at 629 .

203. 272 Cal. App. 2d 366, 77 Cal. Rptr. 378 (1st Dist. 1969); cf. Pacific Factor Co. v. Adler, 90 Cal. 110, 27 P. 36 (1891); Morris v. Harris, 127 Cal. App. 2d 476, 274 P.2d 22 (1st Dist. 1954) (violation of CAL. ANN. Bus. \& Prof. Code $\$ 16600$ (West 1968)). 
important than party autonomy, even in very-hard-to-calculate-harm cases. Thus, as policies of fostering competition are stronger, chances of upholding liquidation clauses in such cases grow weaker.

\section{H. Contracts to Lend Money}

Two early supreme court cases, Thompson v. Gorner ${ }^{204}$ and Finger v. McCaughey, ${ }^{205}$ held that, because late payment charges are not penalties but alternative methods of performance, there is no breach in such cases and therefore no need to apply sections 1670 and 1671 . In recent cases debtors have sought to change this rule and apply the Freedman doctrine to lending situations, but these attempts have been unsuccessful. The leading recent case, Hellbaum v. Lytton Savings \& Loan Association, ${ }^{206}$ held that a prepayment penalty does not fall within the Freedman doctrine, because it is not a breacli but an alternative method of performance. Two other recent cases similarly held that late payment charges do not fall withm the prohibition of section 1670 since they too are alternative performances. ${ }^{207}$

There is, however, some uncertainty. While Los Angeles City School District v. Landier Investment $\mathrm{Co}^{208}$ did not involve a lending transaction, it is a case concerning contractual remedies for nonpayment of money where the court refused to use the alternative performance technique to uphold a late payment penalty, and it must therefore be considered. Landier entered into an illegal contract for bus transportation of pupils of the Los Angeles City School District. When the facts became known, the school district brought an action for the total payments illegally made, about $\$ 1,500,000$. Prior to trial, the school district and Landier entered into a stipulation settlement suggested by Landier under which he agreed to pay $\$ 264,000$ in eight installments over a period of time, but if he did not pay any installment within 30 days of a due date, the school district would take a judginent for double the outstanding anount remaining. Landier paid $\$ 99,000$ and then defaulted, and the school district sought a judgment of double the outstanding remaining balance, about $\$ 320,000$.

204. 104 Cal. 168, 37 P. 900 (1894).

205. 114 Cal. 64, 45 P. 1004 (1896). See note 90 supra for a discussion of the measure of recovery for a failure to pay money.

206. 274 Cal. App. 2d 456, 79 Cal. Rptr. 9 (1st Dist. 1969). Hellbaum also leeld a due-on-sale clause was not an invalid restraint on alienation. But La Sala v. American Sav. \& Loan Ass'n, 5 Cal. 3d 863, 489 P.2d 1113, 97 Cal. Rptr. 849 (1971), held a due-on-further-encumbrance clause was valid only if it were necessary to protect the lender's security imterest.

207. Walsh v. Glendale Fed. Sav. \& Loan Ass'n, 1 Cal. App. 3d 578, 81 Cal. Rptr. 804 (2d Dist. 1969); O'Connor v. Richmond Sav. \& Loan Ass'n, 262 Cal. App. 2d 523, 68 Cal. Rptr. 882 (1st Dist. 1968). See La Sala v. American Sav. \& Loan Ass'n, 5 Cal. 3d 864, 489 P.2d 1113, 97 Cal. Rptr. 849 (1971).

208. 177 Cal. App. 2d 744, 2 Cal. Rptr. 662 (2d Dist. 1960). 
The court of appeals affirmed a judgment for the school district upon the procedural grounds that relief from the stipulation had not been sought promptly enough. Then, in extended dictum, the court went on to consider the validity of the double-the-outstanding-balance clause. Citing Freedman, the court stated that sucli a double-damage provision is an unenforceable penalty, especially when, as here, at the time the contract is made the actual damages for nonperformance are known and the stipulated amount is not a genuine attempt to preestimate. It would have been better had the court emphasized the settlement aspect of the case and avoided the dictum relating to liquidation for breaches of promises to pay money.

\section{Miscellaneous Contracts}

A number of situations do not fit convemiently in any of the above categories. They are briefly discussed in this section.

\section{Litigation Settlement Agreements}

Two cases have been decided that imvolved litigation settlements providing for stipulated damages. One, Los Angeles City School District v. Landier Investment Co., ${ }^{209}$ has been discussed earlier; ${ }^{210}$ while in lengthy dictum the court declared it would normally refuse to enforce a stipulated remedy, for procedural reasons the court enforced the agreement. The second case, Daddino v. Builders Concrete, Inc., ${ }^{211}$ imvolved a settlement agreement incident to nuisance litigation. In an action brought by a farmer, a ceinent plant was found to be a nuisance; the trial court awarded damages and permanently enjoined the plant from operation. In exchange for being given the right to continue production until October, the cement company agreed to pay plaintiff $\$ 50$ a day for each day past October 17, 1956, that the factory operated. When the plant operated beyond the deadline, the farmer sued and won a judgment for $\$ 2,750$ under the liquidation provision. The appellate division of the superior court affirmed, noting how difficult it would have been to estimate damages, that the amount seemed within reason, and that it was arrived at by the negotiations of counsel.

\section{Partnership Contribution Agreements ${ }^{212}$}

The pattern established by the few cases on liquidation in part-

209. Id.

210. See text accompanying note 208 supra.

211. 168 Cal. App. 2d Supp. 781, 334 P.2d 1067 (Sup. Ct., App. Dep’t 1959).

212. Covenants not to compete incident to partnership agreeinents are discussed in text accompanying notes 190-92 supra. 
nership contribution agreements is that if the agreement is reasonable, it will be enforced. For example, the agreement in Hill v. Hearron ${ }^{213}$ contained a blunderbuss penalty clause providing that if a partner did not perform in accordance with the agreement he would forfeit his interest in the partnership. The appellate court applied the Freedman concept to the transaction and held that the defaulting partner was entitled to the net benefit he conferred upon the partnership and his breach, though willful, did not automatically cause a forfeiture of his entire partnership interest.

In contrast, the agreement in Feiger $v$. Winchell ${ }^{214}$ gave a partner the option of either meeting the call for more capital or having his profit-or-loss percentage adjusted. In effect, the court held that this was a case of alternative performances, ${ }^{215}$ and therefore it did not have to comply with section 1670; the partner could either pay or have his profit ratio reduced. However, the court declared that even if it were a liquidation provision it would be upheld, because at the time the partnership agreement was made, the

transaction . . . was very highly speculative and it was almost impossible at the time of entering into the partnership to foresee with any degree of accuracy the amount of profits or losses there might be. At the time of entering into the partnership agreennent it was impractical and extremely difficult to fix the actual damages that might result in case of a breach. ${ }^{216}$

This may be true; perhaps the enterprise could not borrow additional money and would collapse without the contribution. But it still appears to be a promise to pay money, and liquidation is generally not allowed in this situation. ${ }^{217}$

\section{Insurance Contracts}

Usually, the insured does not promise to pay premiums, and forfeiture is prevented by other doctrines, but Kelly v. Great Western Accident Insurance Co. ${ }^{218}$ involved the execution of a five-year note by the insured for premiums of $\$ 60$ a year. The insured did not make the second payinent after demand and then killed himself. The beneficiary attempted to collect on the policy, arguing that a provision providing for forfeiture in the event of nonpayment came under sections 1670

213. 113 Cal. App. 2d 763, 249 P.2d 54 (3d Dist. 1952).

214. 205 Cal. App. 2d 123, 22 Cal. Rptr. 901 (2d Dist. 1962).

215. Corbin agrees. 5 CORBIN $\S 1070$.

216. $205 \mathrm{Cal}$. App. 2d at 130, 22 Cal. Rptr. at 905. See text accoinpanying notes 220-26 supra.

217. See 5 CoRBIN $\S 1065$ (arguing that a promise to pay money cannot be liquidated unless there are consequential damages).

218. 46 Cal. App. 747, 189 P. 785 (1st Dist. 1920). 
and 1671. The court agreed and held for the beneficiary when the insurance company failed to establish compliance with section 1671 .

\section{Goodwill}

Where the breach in question relates to and affects goodwill, courts typically enforce liquidated damages clauses, as is shown by the many cases that permit even lump sum liquidation clauses to be enforced in covenants not to compete-even without the necessity of pleading and proving compliance with section $1671 .^{210}$ Goodwill considerations have also led courts to enforce liquidation clauses in other situations where liquidation is not generally permitted. ${ }^{220}$

\section{IV}

\section{CRITERIA FOR ENFORCEABILITY}

\section{A. Type of Harm}

The most important criterion for enforceability is wliether damages for the type of harm that is contemplated are "impracticable or extremely difficult to fix" as required by section 1671 . This is sometimes referred to as the "difficulty of ascertainment" test. This statutory language leaves unanswered two principal questions: First, at what time must the actual damages be difficult to ascertain? Second, precisely how mucli uncertainty is necessary? The section discusses the courts' reactions to these problems.

\section{Contract Orientation or Trial Orientation?}

One possibility is to focus attention upon the time when the contract is made-the look-forward rule. The court must put itself in the position the parties were in and try to determine whether the anticipated harm would be impracticable or extremely difficult to fix. This emphasis upon the situation at the time the contract was made often obscures an important differentiation. Does the required difficulty relate to (1) the amount of damages that will actually be suffered or (2) to the difficulty of establishing the amount even after the facts surrounding the breach are established? If (1) is the standard, there is almost open-ended autonomy to control damages, because the facts that establish the amount will not, as a rule, be known until breach. If enforceability requires compliance with (2), the "look-forward" means that even with the benefit of the facts surrounding the breach, damages

219. See text accompanyimg notes 183-87 supra.

220. See, e.g., McCarthy v. Tally, 46 Cal. 2d 577, 297 P.2d 981 (1956). 
must be difficult to establish because of the absence of a well-recognized and easily workable measure of recovery.

The principal justifications for (1) are either to reward the contracting party who guesses best or to provide a means of letting the parties know what a breach will cost the breaching party at the time the contract is made. This is certainly desirable when contract breach can potentially be open ended. Undoubtedly, this was the principal reason for enforcement of the liquidation clause in the Better Foods case. ${ }^{221}$ Yet, the same justification can be given to a clause limiting liability.

Even if emphasis is upon the difficulty of establishing damages at the time of the trial, we are still concerned with letting the parties know their exposure at the time they make the contract. However, we do not need to give them autonomy unless they are entering into a transaction where damages will be difficult to establish at the time of trial.

The other possibility is to emphasize the time the breach occurred or, more realistically, the time of trial. ${ }^{222}$ The rationale for this rule is that it restricts the use of liquidation to those times when the court cannot do a decent job of assessing actual damages. Thus, it avoids potential unjust enrichment and the seeming imjustice of enforcing a clause when actual damages are much different from the liquidated sum. While theoretically these time references are mutually exclusive, in practice the differences are not absolute. The issue is one of emphasis: A look-forward court empliasizes the situation that existed at the time the contract was made but does not ignore actual damages; a trial-oriented court is primarily concerned with the clause as a means of making "possible a definite and adequate remedy in place of a more doubtful and inadequate one offered by the law," ${ }^{223}$ but it may also consider the situation at the time the contract was made. The lookforward test has been adopted in California. The leading recent case is Better Foods Markets, Inc. v. American District Telegraph Co. ${ }^{224}$ This case involved a contract for the furnishing of burglar alarm services with a $\$ 50$ liquidation figure. ${ }^{225}$ After quoting the statutory test, the court unequivocally stated:

The plaintiff argues that there is no difficulty in the present case in fixing the actual danage and that the amount of money stolen

221. Better Foods Mkts., Inc. v. American Dist. Tel. Co., 40 Cal. 2d 174, 253 P.2d 10 (1953).

222. Note, supra note 42 , at 235-36.

223. 5 CORBIN $\$ 1058$, at 339.

224. 40 Cal. 2d 174, 253 P.2d 10 (1953).

225. See text accompanying notes 146-48 supra. 
should be the actual damage. Its contention is that the time for the determination of the question of the impracticability and difficulty in fixing the damages is after the loss has occurred. This is not the rule. In determining this question the court should place itself in the position of the parties at the time the contract was unade and should consider the nature of the breaches that might occur and any consequences that were reasonably foreseeable. ${ }^{226}$

Unfortunately the court used "look-forward" in sense (1) rather than sense (2). At the time the contract was made, the facts surrounding the breach could not be known, so the amount of damage was impracticable or extremely difficult to fix. But the amount of damage could be determined at the time of trial. The only justification for the court's "look-forward" analysis would be problems of causation; even at trial time it would be difficult to determme whether the alarm company's breach caused the loss.

A later supreme court case, McCarthy $v$. Tally, ${ }^{227}$ and several early lower court cases ${ }^{28}$ concur in this holding, although in all but Better Foods, taking aside the difficult causation question, the courts' statements on this issue were gratuitous in that it is likely in those cases that damages would have been difficult to establish even at the time of trial. In fact, even Better Foods did not raise the issue squarely; there the court was dealing with a limitation of liabihty that should have been upheld as such. Nevertheless, the look-forward rule is clearly established in Califorma.

\section{What Damages Are "Impracticable or Extremely Difficult to Fix"?}

The second important question in the difficulty-of-ascertainment area relates to determining what is "impracticable or extremely difficult." A few cases have attempted to elaborate upon the statutory language, stating that hiquidation would be allowed where damages are "absolutely uncertain"229 or "uncertain and not susceptible to computations," matter to ascertain" 231 or "readily computable."232 Taken together,

226. 40 Cal. $2 d$ at $184-85,253$ P.2d at 14 .

227. 46 Cal. 2d 577, 297 P.2d 981 (1956).

228. Starr v. Lee, 88 Cal. App. 344, 263 P. 376 (1st Dist. 1928); Hanlon Drydock \& Shipbuilding Co. v. G.W. McNear, Inc., 70 Cal. App. 204, 232 P. 1002 (1st Dist. 1924).

229. Potter v. Ahrens, 110 Cal. 674, 681, 43 P. 388, 389 (1896).

230. Pogue v. Kaweah Power \& Water Co., 138 Cal. 664, 668, 72 P. 144, 145 (1903).

231. Sherman v. Gray, 11 Cal. App. 348, 352, 104 P. 1004, 1005 (1st Dist. 1909).

232. Robert Marsh \& Co. v. Tremper, 210 Cal. 572, 576, 292 P. 950,952 (1930). 
these emphasize that hquidation will not be permitted when the actual damages or the anticipated damages can be computed by application of a well-established damage measure that can furnish a solution without great difficulty.

More valuable than these verbal formulations is a review of what the courts liave done. First, there are certain situations in which courts usually will not enforce a liquidation clause. For example, liquidation clauses have not been enforced where the breach relates to furnishing legal services ${ }^{233}$ and in contracts involving brokers' services. ${ }^{234}$ Courts have also generally refused to enforce liquidation clauses in goods contracts $^{235}$ and leases. ${ }^{236}$ Second, courts liave frequently refused to allow liquidation where an explicit provision of the Civil Code establishes damages for a particular type of breach. In Greenleaf $v$. Stockton Combined Harvester \& Agricultural Works, ${ }^{237}$ for example, the court refused to enforce a provision claimed by appellant to liquidate damages for breach of warranty because the Civil Code set the measure of recovery and therefore it was not impracticable or difficult to fix damages. Similarly in Drew v. Pedlar, ${ }^{238}$ a defaulting-plaintiff-landcontract case, the court stated that section 3307, which provides "a rule by which the damage, in all cases of this kind, may be measured and definitely fixed," ${ }^{239}$ precluded liquidation. And in Knight v. Marks, ${ }^{240}$ a case involving a 10-year lease, the court refused to enforce a purported hquidated damages clause because section 3302 set the amount due on the obligation plus interest as the measure for failure to pay money. ${ }^{241}$

Courts that refuse to enforce liquidation clauses because they find the measure of recovery sufficiently easy to work with sometimes indicate liquidation is possible where special damages are contemplated at the time the contract is made. ${ }^{242}$ For example, in Stark v. Shemada, ${ }^{243}$ the court stated:

Circumstances may arise where, when the property is purchased for a special purpose, or has a special value, special damages may be allowed, but the facts as here pleaded ... [do] not take the case out of the general rule. ${ }^{244}$

233. See text accompanying notes 128-30 supra.

234. See text accompanying notes 123-27 supra.

235. See text accompanying notes 94-115 supra.

236. See text accompanying notes 76-93 supra.

237. 78 Cal. 606,21 P. 369 (1889).

238. 87 Cal. 443,25 P. 749 (1891).

239. Id. at $450,25 \mathrm{P}$. at 751 .

240. 183 Cal. 354, 191 P. 531 (1920).

241. But see note 90 supra.

242. But see Greenbach Bros., Inc. v. Burns, 245 Cal. App. 2d 767, 54 Cal. Rptr. 143 (1st Dist. 1966).

243. 187 Cal. 785, 204 P. 214 (1922).

244. Id. at 788,204 P. at 216. 
A similar exception might be appropriate in another type of case. Many measures of recovery, such as those for defaults in sales of goods or land, are based upon the difference between contract and market prices at the time of breach. ${ }^{245}$ However, subject to the rules relating to foreseeability, there may be additional damages, such as unusual resale profits. In such a case, it may be permissible to liquidate damages for that particular risk.

There are also certaim types of cases where courts have typically enforced liquidation clauses, such as covenant-not-to-compete cases ${ }^{246}$ and contracts to explore for oil. ${ }^{247}$ A liquidation clause would also very likely be enforced where a breach by an employer in the payment of wages to a union member would do irreparable harm to the prestige of the umon, ${ }^{248}$ where a inarketing cooperative association member injures the reputation of the association by not dehivering as promised, ${ }^{249}$ or where the hiquidated breach affects goodwill. ${ }^{250}$ Finally, hquidation is permitted for construction delay. ${ }^{251}$

The clearest distinction is that, in eacli of the cases where hiquidation was allowed, it was relatively clear that there was some damage, but the amount would have been very difficult to prove, even at the time of trial. The prediction of the parties is just as good as the court's at the time of trial. On the other hand, in cases where liquidation has not been permitted, while proof of the amount of damages is not always clear cut-attorneys may differ in valuing legal services, experts may differ in valuing broker services, and there nay be questions as to the proper market and whether the price obtained or paid was reasonable-valuing the actual damages is not beyond the skill and expertise of a court; therefore, the need for contract-specified amounts is not as pressing. This distinction is the best predictive guide in this field: Courts are likely to validate clauses where the actual damages are difficult to measure even at the time of trial and are unlikely to validate clauses where the measures of recovery for actual damages are relatively simple to work with and can produce a reasonably rational solution. Corbin sums it up this way: Clearly, the harm is liquidatable where the evidence would be too uncertain to go to a jury; the harm should also be liquidatable where there is enough evidence to go to a jury, but

245. See Cal. Civ. Code $\S \S 3306-07$ (West 1970); CaL. Comm. Code $\S \S 2708$, 2713 (West 1964).

246. See text accompanying notes 183-92 supra; 5 CoRBIN $\$ 1062$.

247. See text accompanying notes $117-22$ supra; 5 CoRBIN $\S 1062$.

248. California State Council of Carpenters v. Superior Court, 11 Cal. App. 3d 144, 89 Cal. Rptr. 625 (4th Dist. 1970).

249. Seid Pak Sing v. Barker, 197 Cal. 321, 240 P. 765 (1925).

250. McCarthy v. Tally, 46 Cal. 2d 577, 297 P.2d 981 (1956) (dictum).

251. See text accompanying notes 163-77 supra; 5 CoRBIN $\S 1062$. 
the difficulty of proof ... may be . . . such as it make estimation impossible by mathematical processes or by the use of cstablished market prices or by any other definite standard of valuation. ${ }^{252}$

Thus, though the announced test is look-forward, what counts is the convenience and efficiency by which actual damages can be measured at trial.

\section{B. Process By Which Stipulated Amount Is Determined}

No requirenient that the anrount specified as liquidated damages be determined in any particular way appears in section 1671 , but case law clearly has added such a requirenient for enforcing a liquidation clause. Again, the leading cases are Better Foods and Tally. In Better Foods the supreine court stated that the amount "must represent the result of a reasonable endeavor by the parties to estimate a fair average conipensation for any loss that niay be sustamed."253 Similarly, in Tally the court declared there inust be a "reasonable endeavor to ascertain what such damages would be."254 The supreine court cases einphasize a reasonable process to predict damages, although the reasonableness of the amount or formula chosen is also likely to be crucial. This is because the probable injury the parties had reason to foresee largely determines whether they niade any attenipt to predict damages, let alone a reasonable one. ${ }^{255}$ It is perhaps because of this that the lower courts that have considered the problen froni a broad standard of honesty and good faith to a somewhat narrower standard of reasonableness. ${ }^{250}$

In most cases there is little evidence of the process by which the stipulated anounts are determined, but a few cases have touched upon the problem of applying the abstract standard to actual facts. One, Leslie v. Brown Brothers, Inc., ${ }^{257}$ went directly into the question of how the ainount was determined. The performing party had put up a note and security for $\$ 7,500$ that was to be forfeited if he did not make certain agricultural improvements by a given date. A witness for the nonperforming party was asked:

[The note and security] were simply put up, as I understand it, as a penalty in the event he didn't complete the contract, is that right?

252. 5 CORBIN $\$ 1060$.

253. $40 \mathrm{Cal} .2 \mathrm{~d}$ at 187,253 P.2d at 15 .

254. $46 \mathrm{Cal} .2 \mathrm{~d}$ at 586,297 P.2d at 987.

255. 5 CORBIN $\$ 1072$. Corbin favors reasonableness as the standard. Id. $\S 1063$.

256. See People v. Central Pac. R.R., 76 Cal. 29, 36, 18 P. 90, 94 (1888); Hanlon Drydock \& Shipbuilding Co. v. G.W. McNear, Inc., 70 Cal. App. 204, 218, 232 P. 1002, 1008 (1st Dist. 1924).

257. 208 Cal. 606, 283 P. 936 (1929). 
The witness answered yes to this question and then was asked:

In other words, you were not going to pay him anything for those notes and inortgages, but would keep them if he didn't comply with the contract within the time inentioned. A. That is the idea..58

While the court seemed to base its refusal upon the absence of a process to estimate damages, it is likely that the real reason was the ease with which actual damages can be established.

In Daddino v. Builders Concrete, Inc., ${ }^{259}$ the court, after noting the difficulty in estimating damages caused to a farmer by an adjacent factory, emphasized that the amount was determined by the negotiations of counsel for both parties. Because the potential damages were extremely difficult to estimate and the parties were represented by counsel, the court paid little attention to the process by which the liquidation amount was selected.

Clearly, Daddino is typical of what courts normally do. While we have little data on low liquidation amounts are determined, what data we do have shows that, even in fields where liquidation clauses are generally upheld, the process of selecting a liquidation figure does not meet the articulated test. For example, courts generally enforce liquidation clauses when a contractor on a public project fails to meet deadlines; yet, as noted earlier, a California highway engineer has explained that the amount selected for liquidated damages provisions in roadbuilding contracts is not an attempt to estimate damages but simply a device to ensure that the contractor takes his completion date seriously in projects of urgency. ${ }^{260}$ Even whien, as in land contracts, the parties actually engage in bargaining, they do not bargain over damage estimates. For example, in Caplan v. Schroeder ${ }^{261}$ the $\$ 15,000$ deposit was bargained out but represented what the parties thought a six-month riglit to purcliase, which caused a tie-up of the land, was worth; it was not their estimation of damages. Similarly, it is likely that the customary flat amount or percentage deposit is not based upon an evaluation of actual damages over many transactions but is selected without any attempted estimation of damages. ${ }^{262}$ As noted in Caplan v. Schroeder, ${ }^{263}$ generally both parties think that the land will rise in value, and, if this is so, the amount selected cannot possibly be an estimate of damages. With the emergence of more mass-

258. Id. at $617,283 \mathrm{P}$. at 940 .

259. 168 Cal. App. 2d Supp. 781, 334 P.2d 1067 (Super. Ct., App. Dep’t 1959).

260. See the discussion of the work of engineer Elliott in H. JONES, A. FarNsWORTH \& W. Young, supra note 175.

261. 10 Cal. Rptr. 399, 401 (Cal. App. 4th Dist.), rev'd, 56 Cal. 2d 515, 364 P.2d 321, 15 Cal. Rptr. 145 (1961). See also Smitlı v. Royal Mfg. Co., 185 Cal. App. 2d 315, 8 Cal. Rptr. 417 (1st Dist. 1960).

262. See 5 CORBIN $\$ 1058$.

263. 56 Cal. 2d 515, 520, 364 P.2d 321, 324, 15 Cal. Rptr. 145, 148 (1961). 
produced forms created by the dominant party, we can expect even fewer stipulated damages that are actually a jointly determined estimate of actual damages.

Although it is rare that a hquidation amount is selected in a process that is a reasonable endeavor by the parties to estimate the damages for any loss that may be sustained, liquidation clauses are nevertheless enforced when the actual damages are difficult or impossible to ascertain. It therefore seems that, despite the courts' contrary protestations, it really does not matter what process is used to select liquidation amounts as long as the amount selected is within the realm of reason.

\section{Actual Damages}

Frequently, the party seeking to invalidate a hquidation clause wishes to show that the actual damages suffered, if any, were substantially less than the stipulated liquidation damages. Less frequently, a party may seek to avoid enforcement of a liquidation clause by arguing that actual damages were substantially greater than the stipulated liquidation damages. When faced with these problems, a court must reconcile its function of awarding only compensatory damages with rules that often make it appear that the award exceeds actual damages. ${ }^{204}$

While an occasional court has bluntly stated that actual damages are not relevant, ${ }^{265}$ it is generally accepted that actual damages are relevant for certain purposes. For example, the actual damages inay help determine whether the liquidation amount was established as the result of a reasonable endeavor to estimate the damages. ${ }^{266}$ However, despite an early case taking the contrary view, ${ }^{207}$ it is now well established that the plaintiff need not allege nor prove any actual damages. ${ }^{268}$ Yet, if the defendant can show that there have been no actual damages, the court may rely on this factor to support a holding denying enforcement of the liquidation clause. For example, in Eva v. McMahon ${ }^{269}$ the court stated:

Here the plaintiff had sustained no dannage at all, and it would seem to violate all rules of honesty and fair dealing to allow him to take from the defendants the large sum claimed.

264. Comment, Liquidated Damages and the "No Harm Rule," 9 STAN. L. Rev. 381, 386 (1957).

265. E.g., Streeter v. Rush, 25 Cal. 67 (1864).

266. See Wilmington Transp. Co. v. O'Neil, 98 Cal. 1, 32 P. 705 (1893); 5 CORBIN $\$ 1063$.

267. Kelly v. McDonald, 98 Cal. App. 121, 276 P. 404 (3d Dist. 1929).

268. McCarthy v. Tally, 46 Cal. 2d 577, 297 P.2d 981 (1956). But cf. London Guar. \& Acc. Co. v. Las Lomitas School Dist., 191 Cal. App. 2d 423, 425-26, 12 Cal. Rptr. 598, 599-600 (1st Dist. 1961).

269. 77 Cal. $467,472,19$ P. 872,874 (1888). 
Professor McCormick, an advocate of autonomy, objects to these cases; he would ignore actual damages and enforce a liquidation clause if the amount is "reasonably proportioned to probable loss" judged at the time of the contract. ${ }^{270}$ This conclusion would do violence to the compensation principle, but the compensation principle is not inviolate and in contract law, despite what courts often say, punishment is a factor. ${ }^{271}$ Furtherinore, strong positive arguments, such as assumption of risk and encouragement of the use of liquidation clauses, support McCormick's view. Nevertheless, when directly faced with the question, most American courts will not knowingly enforce a liquidated damages clause where there is no actual damage..$^{272}$

\section{Other Criteria for Enforceability}

In addition to these generally recognized criteria, some other factors may regularly tend to influence whether a liquidation clause will be enforced. This section considers these miscellaneous factors.

Surprisingly, one of these factors has not been the presence of an adhesion context; the cases have paid little explicit attention to the distinction between a negotiated contract and one of adhesion. Perhaps this is due to the relatively recent recognition of this distinction and the paucity of recent cases involving attempts to prescribe stipulated damages in an adhesion context.

A greater recognition of this dichotomy may be presaged by the recent case Bauer v. Jackson. ${ }^{273}$ A contract for the shipment of horses by a common carrier specified an agreed valuation of $\$ 200$ per horse; some horses were injured due to the negligence of the carrier, and the carrier claimed the contract limited his obligation to the agreed valuation of $\$ 200$ each. At common law a carrier could not himit his

270. MCCORMICK $\$$ 149-50.

271. In some special cases, punitive damages can be recovered. See Simpson, Punitive Damages for Breach of Contract, 20 OHro ST. L.J. 284 (1959). Willfulness may deprive a party of forfeiture protection. See Cal. Crv. CoDE $\$ 3275$ (West 1970). The measure of recovery for breach by a seller is affected by the existence of bad faith. Id. $\S 3306$. It is sometimes asserted that a willfully breaching contractor cannot use substantial performance. 3A CoRBIN $\$ 707$. See also RESTATEMENT OF CONTRACTS $\$ 275(\mathrm{c})$ (1932) (listing willfulness as a factor in determining materiality of breach).

272. Caplan v. Schroeder, 56 Cal. 2d 515, 364 P.2d 321, 15 Cal. Rptr. 145 (1961); Freedman v. Rector, 37 Cal. 2d 16, 230 P.2d 629 (1951); Petrovich v. City of Arcadia, 36 Cal. 2d 78, 222 P.2d 231 (1950); Olson v. Biola Cooperative Raisin Growers Ass'n, 33 Cal. 2d 664, 204 P.2d 10 (1949); Webster v. Garrette, 10 Cal. App. 2d 610, 52 P.2d 550 (3d Dist. 1935); White v. City of San Diego, 126 Cal. App. 501, 14 P.2d 1062 (4th Dist. 1932); Mente \& Co. v. Fresno Compress \& Whse. Co., 113 Cal. App. 325, 298 P. 126 (4th Dist. 1931); Jakovich v. Romer, 74 Cal. App. 333, 240 P. 39 (1st Dist. 1925).

273. 15 Cal. App. 3d 358, 93 Cal. Rptr. 43 (4th Dist. 1971). 
liability, but in Bauer the carrier had filed a tariff schedule pursuant to the Carmack Amendment, ${ }^{274}$ which permits limitation if the amount is reasonable, a tariff is filed with the Interstate Commerce Commission, and the shipper is given the choice of an increased valuation for a higher shipping charge. The court of appeals reversed a trial court holding that the shipper was conclusively bound because he signed a form with the agreed valuation contained in it, arguing that there must be an understanding consent:

In the present case . . . the carrier's agent inserted in the shipping contract a "declared value" of $\$ 200$ per horse without discussing value or choice of rates with the shipper's agent. The shipper's agent testified he had no opportunity to read the document because it was not handed to him until after the horses had been loaded and the truck was ready to leave. An inference can be reasonably drawn that he thought he was merely signing a delivery receipt. He testified he was [not] apprised of the fact that the contract limited recovery for loss or damage to $\$ 200$ per horse . . . . ${ }^{275}$

The court held that consent is a factual question, as is the question of whether the shipper had been given reasonable notice of an alternate rate based on valuation.

There are various other factors courts have suggested that may influence enforceability. One court noted the presence of an attorney for each party in the negotiations leading to a contract containing a hiuidation clause and suggested that this factor aids enforceability. ${ }^{270}$ Indeed, one suspects that one reason the Freedman doctrine evolved in the land-purchase-deposit cases is that buyers, especially buyers of residences, are not often represented by an attorney. ${ }^{277}$ Other courts have declared that it aids enforceabihty if the "amount provided in the contract . . . as liquidated damages is . . not unconscionable"278 and is "in good faith inserted in the contract,",270 suggesting, as would be expected, that a court will not enforce a liquidation clause that offends its sense of justice. This may be why courts are reluctant to enforce a hquidation clause against a party who has good cause, but not

274. 49 U.S.C. $\$ 20(11)$, (12) (1970).

275. 15 Cal. App. 3d at 370, 93 Cal. Rptr. at 50.

276. Daddino v. Builders Concrete, Inc., 168 Cal. App. 2d Supp. 781, 784, 334 P.2d 1067, 1069 (Super. Ct., App. Dep't 1959).

277. Compare Freedman v. Rector, 37 Cal. 2d 16, 230 P.2d 629 (1951) with Better Foods Mkts., Inc. v. American Dist. Tel. Co., 40 Cal. 2d 179, 253 P.2d 10 (1953) and Atkinson v. Pacific Fire Extinguisher Co., 40 Cal. 2d 192, 253 P.2d 18 (1953).

278. Escondido Oil \& Dev. Co. v. Glasser, 144 Cal. 494, 500, 77 P. 1040,1042 (1904).

279. Hanlon Drydock \& Shipbuilding Co. v. G.W. McNear, Inc., 70 Cal. App. 204, 218, 232 P. 1002, 1008 (1st Dist. 1924). 
legal excuse, for nonperformance. ${ }^{280}$ Finally, it appears that a party who determined the amount of the hiquidation and put the clause into the contract will find it more difficult to avoid enforcement of the stipulated damages than the other party. ${ }^{281}$

\section{E. Alternative Performances}

Because sections 1670 and 1671 do not apply if the contract is imterpreted as providing for alternative performances rather than liquidation, one technique for obtaining enforcement of contract-stipulated damages is to meet the test for alternative performances. McCormick states that the test is whether the promisor reasonably believes he has a rational choice of course to pursue. ${ }^{282}$ If there are true alternatives, performance of either will discharge him.

The cases liave not probed deeply into the alternative performance question: an insurance salesman may not have a rational choice as to whether he will continue working or lose his renewal commission; ${ }^{283}$ a debtor may not have a real choice as to whether to pay on time or pay shightly later at a much higher rate; a buyer may not really decide to purcliase the land or lose his downpayment. As a result, the alternative performance doctrine has become a useful tool to enforce a reasonable remedy clause without showing compliance with section 1671 .

\section{F. Availability of Specific Performance}

In California it is clear that the availability of a valid liquidation clause does not affect the right to specific performance; Civil Code section 3389 provides that specific performance can be obtaimed in a proper case even if there has been a valid liquidation of damages. ${ }^{284}$

\section{$\mathrm{V}$ \\ LEgISLATIVE REFORMS}

Sections 1670 and 1671 have been California law for almost one hundred years; they have stood without amendment since 1872 . Plainly, any proposal for changing these statutes or adding others to himit their authority must be preceded by the finding that the existing statutory scheme is deficient in some significant way. While the statutes could have been better drafted, one can argue that they are working.

280. See text accompanying note 24 supra.

281. Horrell v. Lakewood Marina, Inc., 3 Cal. App. 3d 506, 83 Cal. Rptr. 701 (4th Dist. 1970); Hanlon Drydock \& Shipbuilding Co. v. G.W. McNear, Inc., 70 Cal. App. 204, 232 P. 1002 (1st Dist. 1924).

282. MCCORMICK \& 154 .

283. Bach v. Curry, 258 Cal. App. 2d 676, 66 Cal. Rptr. 220 (1st Dist. 1968).

284. For a case in a jurisdiction without such a statute, see Bauer v. Sawyer, 8 III. 2d 351, 134 N.E.2d 329 (1956). 
There is no present outcry for reform, and the areas of principal difficulty (advance payments of rent and the deposits made imcident to contracts to purchase land) are quiescent: the worst aspects of the advance deposits in leases were minimized by legislative change in $1970^{285}$ and the land-purchase-contract problem seems to have been taken care of by the dictum in Caplan v. Schroeder ${ }^{280}$ discussed above. ${ }^{287}$

But sections 1670 and 1671 do not state the whole law. First, they do not explain whether the test should be applied at the time the contract is made or at the time of breach. Also, the phrase "impracticable or extremely difficult to fix" is so anbiguous it fails to provide guidance to contracting parties. Thus, attorneys must look to the case law to find that the statutory test should be applied at the time of contracting and that liquidation clauses will be enforced where there is no generally accepted and easily applied measure of recovery. In addition, the second articulated principal test-that there be a reasonable endeavor to estimate actual damages-is not even suggested in the code; it is found only in the Better Foods ${ }^{288}$ and Tally ${ }^{280}$ cases. One possible legislative reform is to amend sections 1670 and 1671 to express the entire law as articulated by the courts.

A second possible avenue for legislative change is to restructure sections 1670 and 1671 to make them conform to what is actually being done in the cases, rather than the articulated standards there expressed. Courts enforce liquidated damage clauses when it is reasonable to do so. Because reasonableness depends primcipally on the difficulty of determining actual dainages at the trial, liquidation clauses are usually enforced only when the trial court needs help: when there are no clear, easily administered formulas for determining actual damages.

A third, and the most desirable, alternative for legislative change would, like the second, make the standard one of reasonableness but would allow more autonomy than the present case law permits. Judicial and legislative limitation on party autonomy to control the amount of damage recognizes that extreme inequality of bargaining power can lead to oppression, violate the compensation principle, create unjust enrichment or undesirable liability limitation, and punish those who breach contracts. However, sections 1670 and 1671 go farther; they reflect 19 th-century hostility to almost all liquidation clauses ex-

285. See text accompanying notes 86-92 supra.

286. 56 Cal. 2d 515, 364 P.2d 321, 15 Cal. Rptr. 145 (1961).

287. See text accompanying note 60 supra.

288. Better Foods Mkts., Inc. v. American Dist. Tel. Co., 40 Cal. 2d 174, 187, 253 P.2d 10, 15 (1953).

289. McCarthy v. Tally, 46 Cal. 2d 577, 584, 297 P.2d 981, 986 (1956). 
cept where it is likely that the amount selected by the parties is as accurate an estimation of actual damages as a court could make. If the contract is negotiated, the parties should be given more leeway to determine damages for breach.

Generally the bargaining process will itself act as a check upon oppression and unjust enrichment, but even in negotiated contracts courts should examine liquidation clauses to assure that they are reasonable. To determine reasonableness, a court should look at the parties and the facts and circumstances surrounding the making of the contract and its breach, and it should estimate the range of actual damages. If the amount specified in the contract falls within the judge's estimation of actual damages, the clause should be enforced. Otherwise, only in those rare cases where the trial judge is confident that the evidence will clearly establislı the actual damages with a minimal expenditure of judicial effort should the clause not be enforced.

Suppose it appears to the judge that a loss has been suffered but that evidence of actual damages would not be sufficient to sustain a damage award because of the proof requirements of foreseeability, causation, or certainty. A clause incorporated in a negotiated contract should be enforced if the risk was assumed, proper performance is very important, and the anount is reasonable in light of the compensation being paid for performance. Enforcement of liquidation clauses under these circumstances means that reasonable penalties in negotiated contracts will be enforced, much like what is already done in public contracts where there is delay. ${ }^{290}$

To give this maximum effect to liquidation clauses in negotiated contracts and to avoid the expenditure of unnecessary judicial energy, California pleading and procedure rules should be changed. Rather than require the party relying on the clause to plead and prove comphance, ${ }^{291}$ the party seeking to avoid the clause should be required

290. See text accompanying notes 168-70 supra.

291. While a few cases [McComber v. Kellerman, 162 Cal. 749, 124 P. 431 (1912); Shafer v. Sloan, 3 Cal. App. 335, 85 P. 162 (2d Dist. 1906)] have enforced liquidation clauses despite failure to plead compliance with section 1671 , generally the party relying on the liquidation clause must plead and prove compliance with that section. Caplan v. Schroeder, 56 Cal. 2d 515, 364 P.2d 321, 15 Cal. Rptr. 145 (1961). However, the court in Bilardi Constr. Inc. v. Spencer, 6 Cal. App. $3 d 771,86$ Cal. Rptr. 406 (1st Dist. 1970), permitted a pretrial order to substitute for the usual requirement that the issue be raised by pleading.

While there have been decisions that seem to require that the specific facts relating to the transaction itself be pleaded, pleading the statutory language and that the amount is a reasonable endeavor to fix the actual damages has been held to be sufficient. See generally 3 B. Witkin, California Procedure § 795 (2d ed. 1971). Many cases state that the validity of the clause is a question of fact. See, e.g., Caplan v. Schroeder, supra; McCarthy v. Tally, 46 Cal. 2d 577, 297 P.2d 981 (1956). But in a few cases, demurrers have been sustained. Better Foods Mkts., Inc. v. American 
to persuade the court that the amount selected will not fall within the range of estimated actual damages and that the requirements for enforcement of a reasonable penalty clause have not been met before any evidence is received on the damages question. In addition, if evidence concerning damages is received, the party seeking to avoid the clause should have the burden of showing that actual damages are different from the stipulated amount.

But $\mathrm{m}$ adhesion transactions there is great risk of oppression and abuse of autonomy. Since there is no bargaiming process, we should not accord even prima facie reasonableness to the amount selected. However, we should not automatically deny even the dominant party in an adhesion contract the power to control damages. Rather, we should scrutinize liquidation clauses in adhesion contracts with great care to determine their fairness, with the burden of showing fairness being upon the proponent of the clause-in most cases, the stronger party. ${ }^{202}$ Moreover, in this situation the clause should be enforced only if the court needs this help in establishing the amount of damages.

This third legislative solution could be adopted by enacting a statute such as the following reworking of Commercial Code section 2718:

Where reasonable, a contractual stipulation of damages for contract breach is valid. Reasonableness may take into account:

1. The contract terms;

2. The facts and circumstances surrounding the making of the contract and its breach;

3. The anticipated harm;

4. The actual harm caused by the breach;

5. The difficulty of proof of loss; and

Dist. Tel. Co., 40 Cal. 2d 174, 253 P.2d 10 (1953); Zurich Ins. Co. v. Kings Indus. Inc., 255 Cal. App. 2d 919, 63 Cal. Rptr. 585 (2d Dist. 1967).

As for satisfying the burden of proof, clearly courts look beyond labels to the surrounding facts and circumstances. See, e.g., Parigian v. Citizens Nat'l Trust \& Sav. Bank, 42 Cal. App. 2d 773, 110 P.2d 117 (2d Dist. 1941); Mente \& Co. v. Fresno Compress \& Whse. Co., 113 Cal. App. 325, 298 P. 126 (4th Dist. 1931). While the intention of the parties usually has not been significant in determining validity, where there is evidence that the clause was intended to coerce the other party such evidence is considered and can often be persuasive. See, e.g., Leslie v. Brown Bros., Inc., 208 Cal. 606, 283 P. 936 (1929); Los Angeles City School Dist. v. Landier Inv. Co., 177 Cal. App. 2d 744, 2 Cal. Rptr. 662 (2d Dist. 1960).

The party relying on the clause need not plead or prove actual damages. McCarthy v. Tally, supra.

While the case law is not clear, it appears that the question of validity will be determined by the judge. See Sun-Maid Raisin Growers v. Paul A. Mosesian \& Son, Inc., 90 Cal. App. 1, 265 P. 828 (3d Dist. 1928).

292. See La Sala v. American Sav. \& Loan Ass'n, 5 Cal. 3d 864, 489 P.2d 1113, 97 Cal. Rptr. 849 (1971). 
6. The inconvenience or nonfeasibility of otherwise obtaining an adequate reniedy.

In addition, the legislature should isolate those transactions that generate oppression or need a more precise standard than reasonableness and provide specialized treatment for those cases. Illustration of such transactions would be land purchase deposits, ${ }^{293}$ education tuition forfeitures, ${ }^{294}$ and late payment charges. ${ }^{295}$

\section{CONCLUSION}

Relatively certain enforcement of clauses controlling the amount of damages in negotiated contracts should encourage both contractmaking and performance and should relieve the already overburdened courts of the frustratimg and difficult process of determining the amount of damages for contract breach.

293. The earnest money cases are an area where it may be particularly desirable to have a precise standard for determining validity. The legislature could provide that use of a statutory schedule specifying a liquidation amount based upon the purchase price ensures validity. A forfeiture based upon the schedule should be valid even if the buyer has a legitiniate excuse for nonperformance, because the parties should be permitted to set an anıunt that the buyer will lose if the contingency that conditions his obligation does not occur. See Rodriguez v. Barnett, 52 Cal. 2d 154, 338 P.2d 907 (1959).

To make certain that the parties give understanding consent, such a statutory plan could require that both buyer and seller initial the paragraph in the contract where the amount is designated and write in the amount by hand.

The statutory schedule should be permissive. If buyer and seller wish to use an amount that deviates from the schedule, validity would be determined in the same way as any other liquidation clause.

294. See text accompanying note 150 supra.

295. See text accompanying notes 204-08 supra. 


\title{
California Law Review
}

\begin{tabular}{lll}
\hline \hline VoL. 60 & JANUARY 1972 & No. 1 \\
\hline \hline
\end{tabular}

\section{BOARD OF EDITORS}

\author{
Editor-in-Chief \\ DENMIS S. KaRJaLA \\ Managing Editor \\ David L. HaMmeTt
}

Notes \& Comments
ROBERT C. BARRETT
LAWRENCE R. BROWN
THOMAS D. CLARK
HENRY C. EAMES, JR.
AUBAN ANN EISENHARDT
JAMES C. FOWLER
ELAINE T. NELSON
ROBERT K. SCHIEBELHUT

Managing

HAROLd G. FRIEDMAN

SCOTT R. WILLERT

Supreme Court Editor

CAROL G. HAMMETT

Associate Editors

DaVid M. Achterkirchen

JOHN F. Davis

CHARLES R. FARRAR, JR.

ROBERT L. HARRIS

JEFFrey M. ALLEN

MICHAEL J. BAKER

Alice M. Beasley

Steven S. Bell

Michael J. Bertinetti

MARSha Siegel BerzoN

DAVID F. BoYle

Gabrielle R. CAMPBell

WIILIAM F. CAPPS

Craig H. Casebeer

RAYMOND A. DIAZ

Joseph P. DiCIUCCIO
SPENCER R. KatTZ THOMAS M. MURRAY LANCE JAY ROBBINS

MARK S. Dodson Paul E. Dorroh JAMES DRUMMY IRA MARK ELLMAN KenNeth James Fishbach, JR. Palmer Brown Madden ERNESTINE FORREST HowARD W. Foss, JR. DAVID M. GIASS Peter Grossman LESLIE ANN JOHNSON RICHARD KAIISH JACK H. KaUfman, JR.

Administrative Assistant Patricta G. SMitra
Articles \& Book Reviews

JIMMIE HARRIS

LYNN H. PASAHOW

Rex Perschbacher

STEPHEN ZAMORA

Research

SteVEn A. Brick

RICHARD MARCUS

Thomas B. Rosengerg

Zona SAge

MARK HAROLd SHENFIELd

SUSAN J. TAMURA

Kevin F. Keliy

STEPHEN L. KostKA

LARY LAWRENCE

DANIEL J. LEER

Craig D. Miller

Oscar Parra

Thomas E. Rankin

Lee Charles Rosenthal

Craig M. Thomas

JOHN E. THORSON

STEPHEN J. YODER 